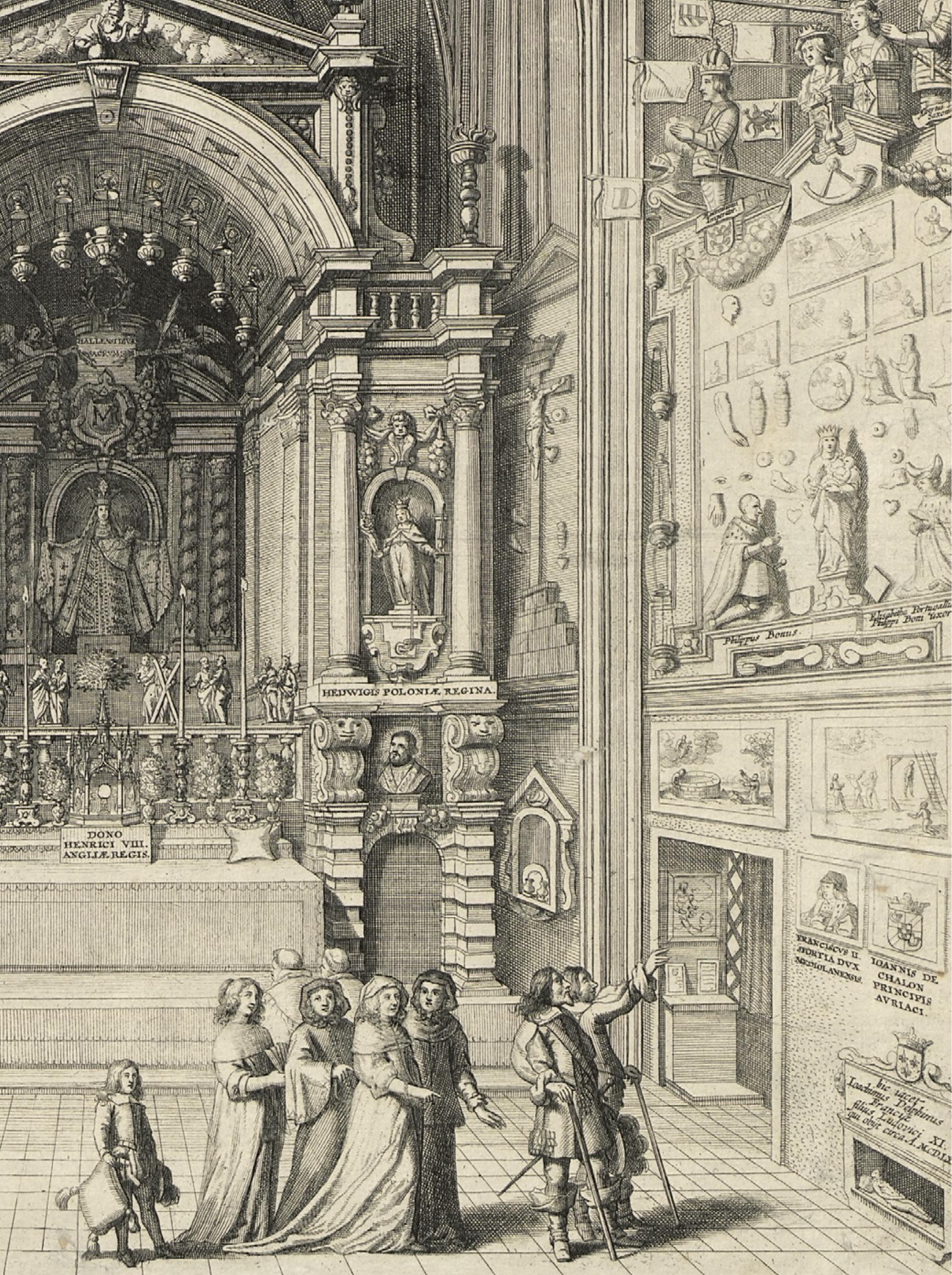




\section{The Resumption of Miracles}

\section{Paulus Gautier's Miracle Memorial Painting}

In a gloomy space, a man is struck by divine light (fig. 128). He is shown twice: kneeling on the right, standing upright on the left. In both cases, he is looking upward with his hands held high. The scene is explained by a text, painted as an unfolded paper document glued to a wooden support in the lower right corner of the painting. Two distinct inscriptions in Dutch and French identify the young man as the leprous Paulus Gautier and date the event to 4 April 1612. ${ }^{1}$ On closer inspection, it is possible to identify both the represented space and the 'here' referred to in the inscription as Zoutleeuw's chapel of Saint Leonard. Indeed, the small cross and the monstrance on the red cloth behind Gautier suggest the presence of an altar, and the sculpture of Saint Leonard represented in the tabernacle above can safely be identified as the particular thaumaturgic object that was venerated in the Brabantine town (fig. 18). In the upper right, votive offerings such as waxen or metal legs, feet and figurines leave no doubt that it was indeed a pilgrimage shrine. Among the ex-votos are two pairs of crutches, and one pair is also depicted lying on the foreground of the scene. All these clues suggest that we are looking at a miracle: Paulus Gautier had long been cripple (estroupié) and therefore walked with crutches, but through the intervention of Saint Leonard in his chapel at Zoutleeuw, he was miraculously cured. As a result, he no longer needed his crutches, which he probably left as ex-voto. The divine intervention itself is depicted quite literally: as a beam of light coming from heaven, pointing straight to the still-crippled Gautier at the right.

Within a month after the miraculous event, the painting was commissioned by the churchwardens from Jacop Lambrechts (doc. 16o6-1616), a painter who regularly worked for both the Zoutleeuw church and town during these years. ${ }^{2}$ Referred to as 'the likeness (contrefeytsel) of Paulus Gautier's miracle', it is an object that eludes easy categorization. Lambrechts clearly made use of the visual conventions of votive paintings, which were a particular, narrative type of ex-voto with a number of standard formal characteristics. ${ }^{3}$
Figure 138, detail Lucas II Vorsterman, The chapel of Our Lady of Halle, Brussels, кв R

(C) RUBEN SUYKERBUYK, 2020 | DOI:10.1163/9789004433106_010

This is an open access chapter distributed under the terms of the CC BY-NC-ND 4.0 license. 
FIGURE 128

Jacop Lambrechts, The

miracle of Paulus Gautier, 1612, Zoutleeuw, church of Saint Leonard PHOTO: GUIDO CONINGX - VZW DE VRIENDEN VAN ZOUTLEEUW

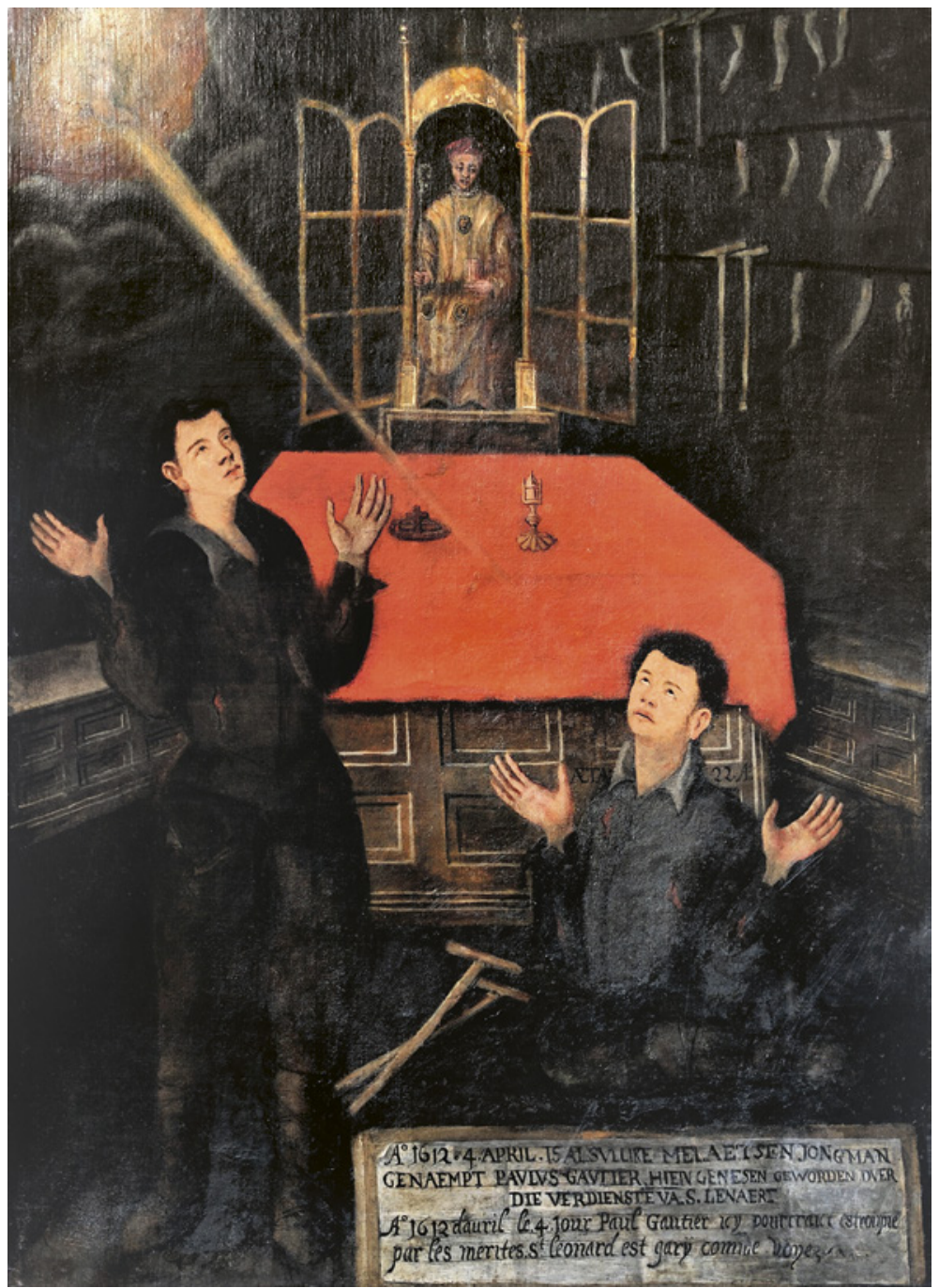

In addition to portraying the worshipper or votary in prayer, they also included a representation of the particular object of devotion, mostly surrounded by clouds or a halo. The scenes are often recognizably set in the actual space where the miracle happened, thus being represented as an accomplished fact. Finally, in addition to the visual information provided by the staging of the scene, the precise intervention is usually clarified in an inscription. ${ }^{4}$ Much like the crutches and figurines depicted on the Gautier canvas itself, donating votive paintings was the final act in the fulfilment of a vow. Yet, through their narrative nature they affirmed 'the efficacy of dialogue between a pious petitioner and a holy intercessor' even more strongly. ${ }^{5}$ Such devotional dialogue is aptly visualized in the votive 


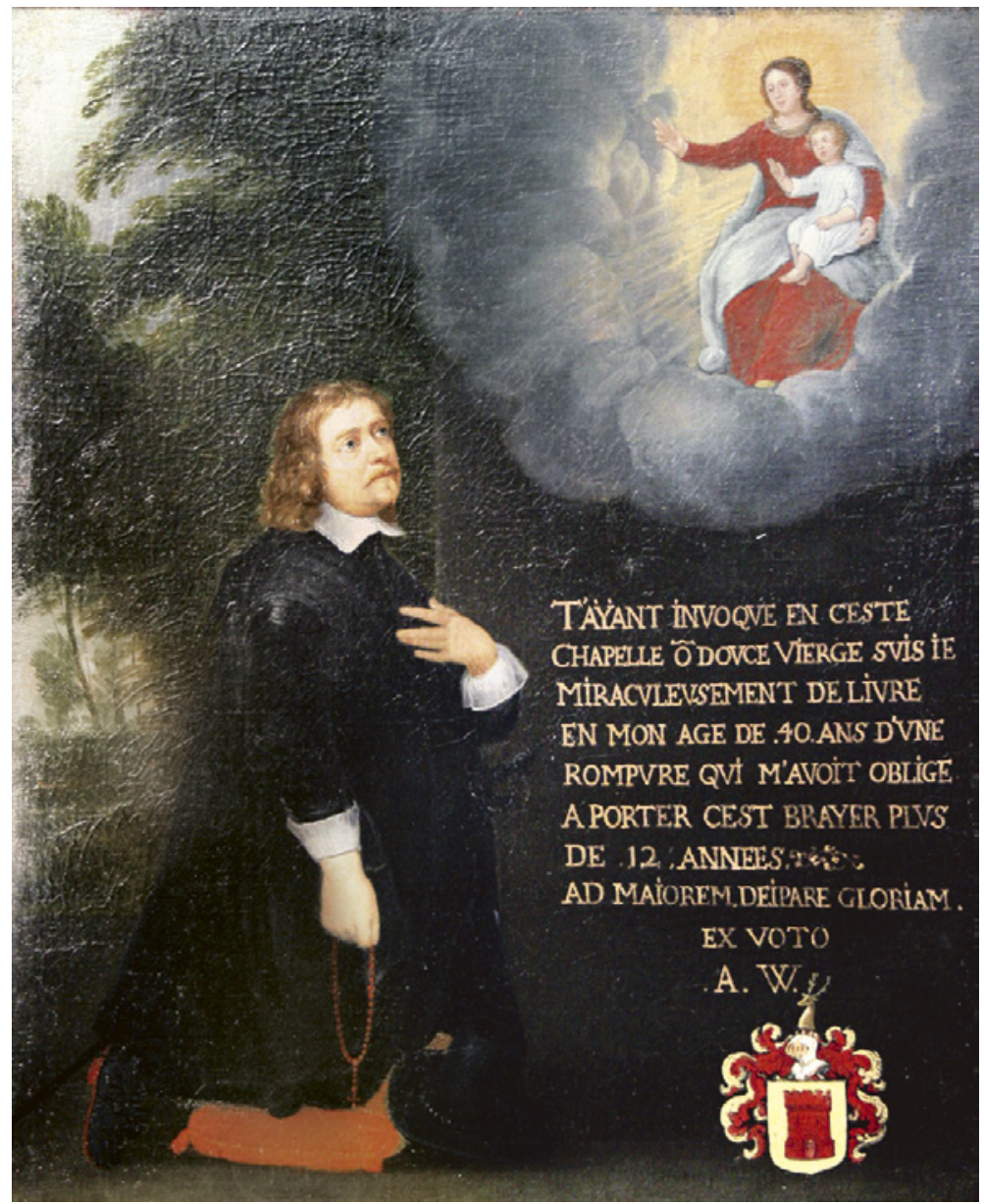

painting that was donated to the shrine of Our Lady at Jezus-Eik by Antonius Walschatten in 1649 (fig. 129). Looking up to Our Lady with the Christ child, seated on a series of clouds and illuminated by a light emanating from the back, Walschatten kneels down on a cushion in a wooded landscape, characterizing this particular shrine's environment. In the accompanying inscription, he addresses the Virgin and thanks her for her intercession:

Having invoked you in this chapel, O sweet Virgin, at the age of 40 years I was miraculously delivered from a rupture that had obliged me to wear this truss for more than 12 years. To the greater glory of the Mother of God. Ex voto. A.W. ${ }^{6}$

Although Gautier's painting clearly makes use of the same visual and iconographical conventions, it cannot be considered a votive
FIGURE 129

Anonymous, Votive painting

of Antonius Walschatten,

1649, Jezus-Eik, church of

Our Lady 
painting stricto sensu, which by definition must be donated as an expression of gratitude for the grace obtained by the miraculé himor herself, or by a close relative - mostly parents - rather than by an unrelated third party such as churchwardens. Although formally akin, functionally it is clearly something else. However, without documentation that allows us to identify the donor, this distinction is often difficult to establish. ${ }^{7}$ It is entirely unclear, for instance, when and by whom the painting discussed in Chapter 4 testifying to the benefactions received by Aegidius vanden Hoeve at Our Lady of the Ossenweg in 1538, was donated, since it was only first described in 1632 .

This categorical confusion is augmented by the absence of precise contemporary terminology. Most descriptions use the broad and generic tafereel in Dutch or tabula in Latin, but this could refer to all sorts of panels, figurative as well as textual. ${ }^{8}$ For example, a painting depicting a number of miracles that once hung next to the altar of Our Lady in Leuven's church of Saint Peter was described as tafereel and tabulis, but the fact that it depicted multiple miracles accompanied by texts in rhymed verses strongly suggests that it was a retrospective anthology of earlier miracles, rather than a painting that was given as votive offering. ${ }^{9}$ In German scholarly literature, this particular type of imagery depicting local miracles is mostly referred to with the somewhat confusing term Mirakelbilder. ${ }^{10}$ As an alternative, I would like to propose to refer to them as 'miracle memorial paintings', in line with the term memorie, which was often used in contemporary Netherlandish sources. ${ }^{11}$ For instance, a painting of the miraculous healing performed by Notre Dame de la Fontaine at Chièvres upon a paralyzed beguine who had fled from the Geuzen from Ghent to Mons in 1579, was described as 'an eternal memory and remembrance of this miracle. ${ }^{12}$ Similarly, three seventeenthcentury paintings preserved in Lede, each depicting a miracle at different points in time (1414, 1582 and 1593), are referred to in accompanying text boards as 'memorial of the miracle' (memorie van het mirakel, fig. 130).

In the Low Countries, this pictorial genre would only really start to develop in the seventeenth and eighteenth century, but paintings depicting local miracles commissioned by shrines themselves existed well before. ${ }^{13}$ We know of an early example connected to Our Lady of 's-Hertogenbosch. After the miraculous sculpture had worked its first healings in 1381 , and after the first miracle was officially recorded on 8 November 1382 , the administrators presented a painting depicting 'the miracle of Our Lady's image' to the Count of 


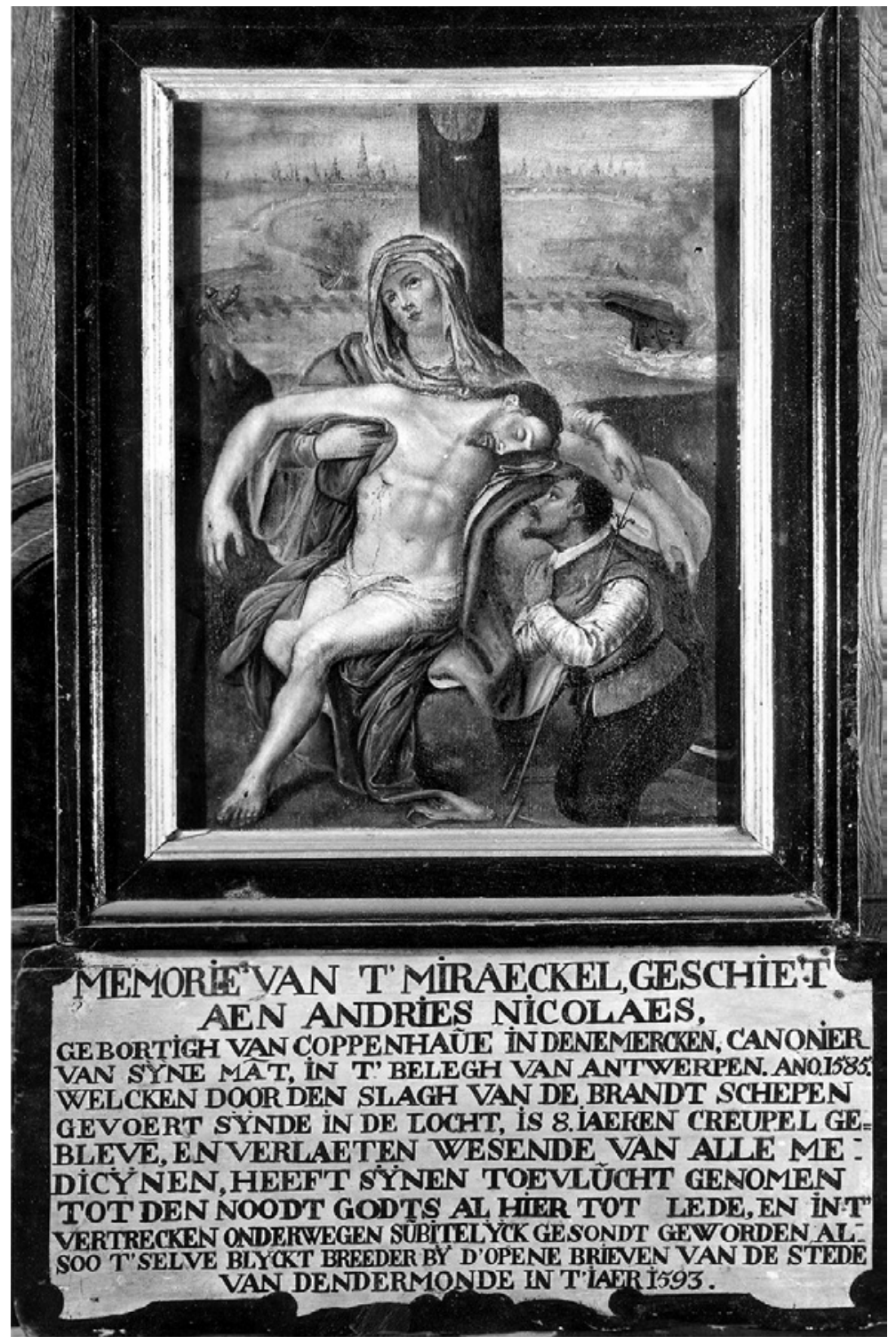

Holland on 19 November of the same year. ${ }^{14}$ Mostly, however, such images were part of larger series. Not unlike the tafereel documented in Leuven, a panel preserved in the church of Our Lady in Damme shows an anthology of six individual miracles worked between 1510 and 1537 by the Holy Cross that was venerated there (fig. 131). The cult object is either shown in its chapel or appearing to the people who invoked it, and the depicted scenes are narrated in Middle Dutch texts at the bottom of the panel. ${ }^{15}$ Other, more ambitious
FIGURE 130

Anonymous (after Otto van Veen), Memorial painting of Andries Nicolaes' miracle, seventeenth century, Lede, church of Saint Martin (C) KIK-IRPA, BRUSSELS 


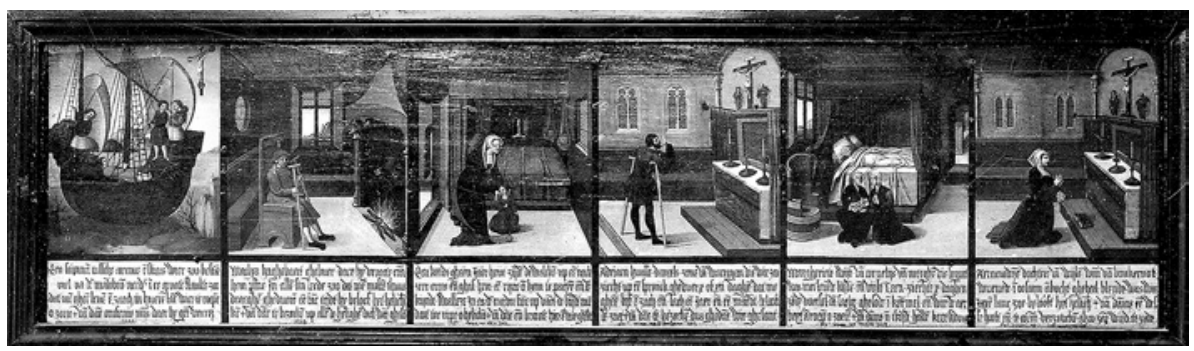

FIGURE 131

Anonymous, Miracle memorial paintings from the Holy Cross of Damme, after 1537, Damme, church of Our Lady

(C) KIK-IRPA, BRUSSELS series visually connected local miracles to the hagiography of the venerated saint. A well-known example is the cycle representing the life and posthumous cult of Saint Rumbold, 25 panels of which are still preserved in Mechelen (figs. 19 \& 132). Originally placed in the chapel where the saint's tomb was located, on the cemetery outside the church (later cathedral), the paintings were probably commissioned by the collegiate chapter after the elevation of Saint Rumbold's relics in 1479 and paid for by the city's most notable inhabitants. ${ }^{16}$ In this case as well, the saint's chapel with its shrine and tomb are clearly recognizable. Now, however, they connect the legendary past of the saint's lifetime with a very specific 'here' for the contemporary observer, visually and emphatically extending the saint's unabated miraculous powers into the present.

Sources for miracle memorial paintings were diverse. Instead of the hagiographical texts traditionally used for the canonical miracles depicted on altarpieces, this type of imagery often had to rely on local miracle books. ${ }^{17}$ For example: the rhyming verses in Middle Dutch explaining the miracle depicted on one of the panels from Mechelen implicitly refer to such a locally consultable written source (fig. 132). ${ }^{18}$ Another example is provided by three exceptional tapestries in the Chapel of Our Lady of the Potterie in Bruges. Woven around 1625 , the compositions of the depicted miracles and the accompanying texts were in fact directly based on a manuscript illustrated with drawings, which was compiled in 1521-1522 and contained miracles from 1499 onwards (figs. 133 \& 134) ${ }^{19}$ However, from around 1600 onwards, such images would increasingly refer to the official documents that had recorded the miracle in question. For instance, one of the panels in Lede refers to 'public letters of the city of Dendermonde from the year 1593' as proof (fig. 130). ${ }^{20}$ In a similar vein, in one of five paintings of the miracles of Our Lady ter Rive in Ghent, the inscription concludes by saying that the event had been 'testified to on 17 June 1603 in front of the aldermen of the seigniory of Sint Pieters', a document which has been preserved in the church's archives (fig. 135). ${ }^{21}$ 


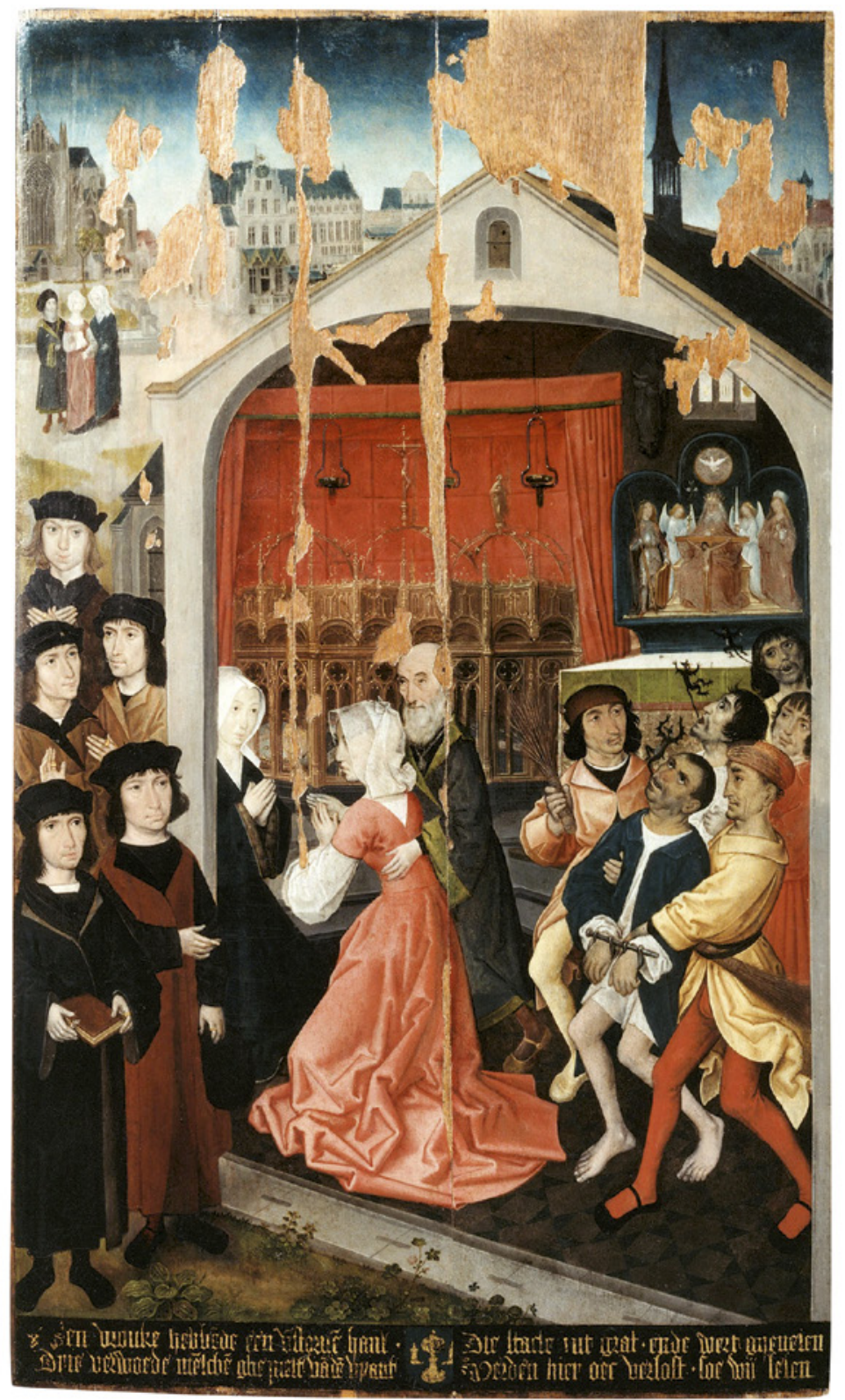

The painting commemorating the miracle of Paulus Gautier shares many characteristics with these examples, since it portrays the event in a specific time and place. Still, it was not part of a larger anthology of wondrous events that had happened in the chapel of Zoutleew, nor was it linked to Saint Leonard's hagiography. The churchwardens had never ordered similar paintings before, and would not do so in subsequent years. In fact, the commission strongly exudes a sense

\section{FIGURE 132}

Master of the Guild of

Saint George, Miracles at the shrine of Saint Rumbold, c. 1500-1503, Mechelen, cathedral of Saint Rumbold (C) KIK-IRPA, BRUSSELS 


\section{FIGURE 133}

Anonymous, Pilgrims in veneration of Our Lady of the Potterie, from the miracle book Myrakelen van onse lieve Vrauwe ter potterye, nr. 12, 1521-1522, Bruges, Museum Our Lady of the Potterie

(C) LUKASWEB - ARTS IN FLANDERS VZW, HUGO MAERTENS

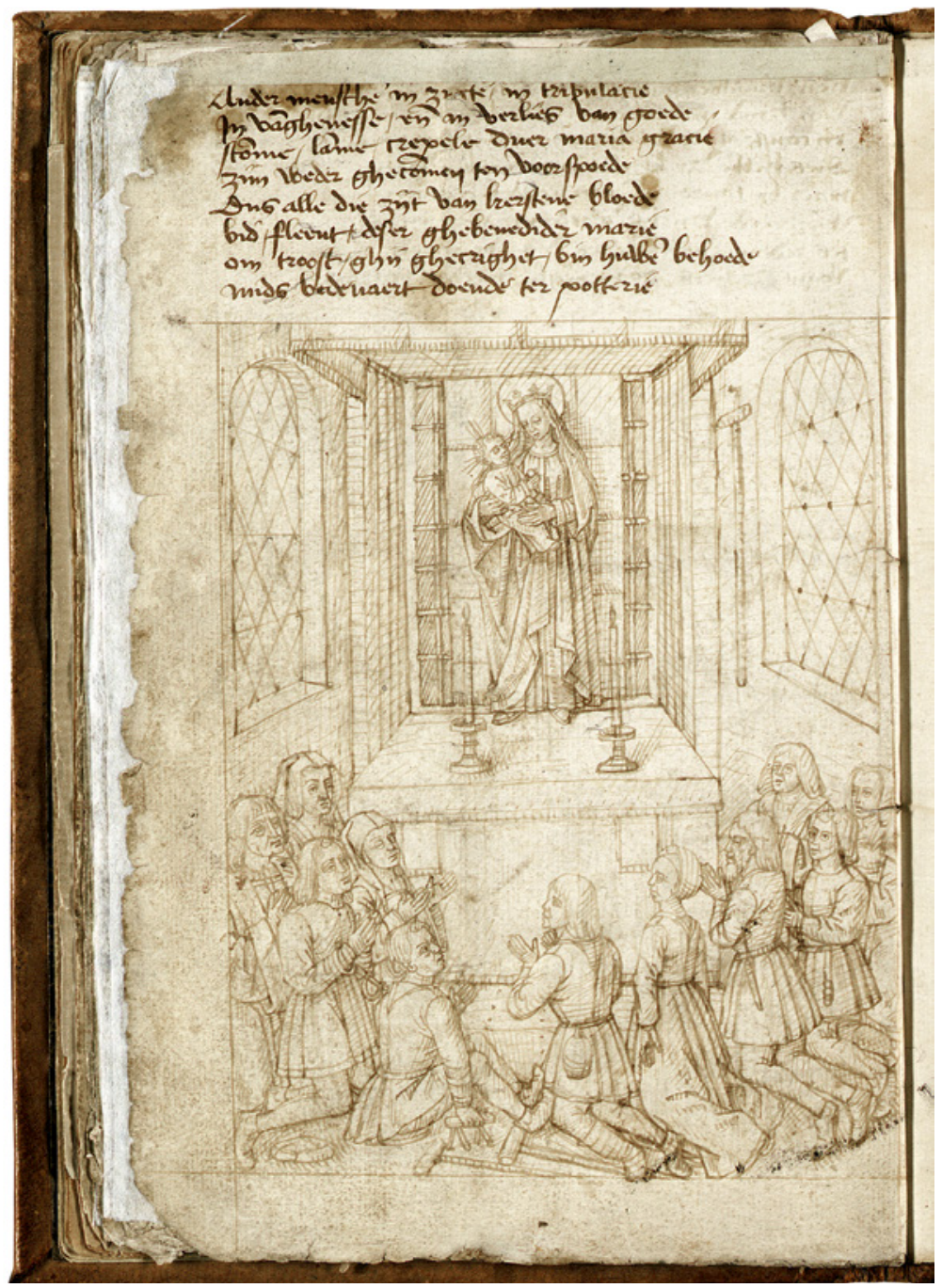

of urgency: it was placed immediately after the miracle had taken place, and the churchwardens clearly opted for quick and relatively cheap action. Why did they suddenly decide to commission this canvas that blurs the boundaries between established genres and functional categories? Who was this Paulus Gautier, and what was the importance of this particular miracle? To understand the intentions of the churchwardens and, by extension, the function of the painting, this chapter analyzes the survival of the cult of Saint Leonard in Zoutleeuw into the seventeenth century. Although there has been a lot of research on Catholic miracle cults in this period, most of it has focused exclusively on the establishment of new shrines or on 


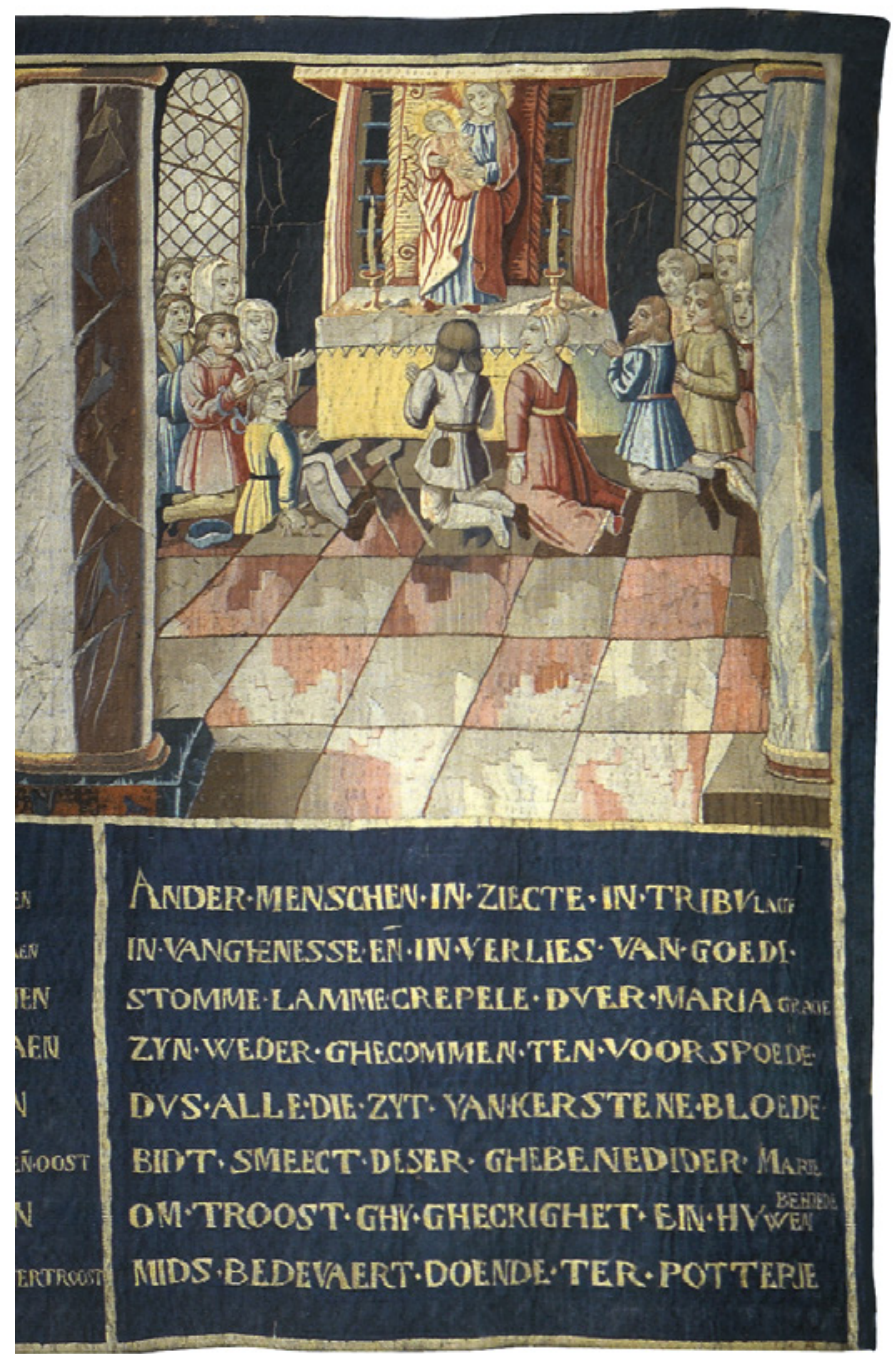

those related to the cult of Our Lady or Christ, usually in the form of the Eucharist. ${ }^{22}$ After all, these were the cults which the Catholic Church tried to prioritize. But what happened to the many cult centers that had flourished around 1500 , which were such a crucial aspect of the Low Countries' devotional culture, after the troubles of the sixteenth century? Cults of saints of late medieval origins now often aroused suspicion, even though they remained an inherent part of the religious landscape. ${ }^{23}$ Iconoclasts and the civil war had seriously damaged both their reputation and furnishing, but traces both material and mental - remained present. ${ }^{24}$ How do the developments in Zoutleeuw fit into the established narratives of how the

\section{FIGURE 134}

Anonymous, Pilgrims in veneration of Our Lady of the Potterie, from the tapestry cycle with miracles of Our Lady of the Potterie, c. 1625-163o, Bruges, Museum of Our Lady of the Potterie

(C) LUKASWEB - ARTS IN FLANDERS VZW, HUGO MAERTENS 


\section{FIGURE 135}

Anonymous, Memorial

painting of the miracle of Ioosyne van Doorslaere, Ghent, church of Our Lady and Saint Peter

(C) KIK-IRPA, BRUSSELS

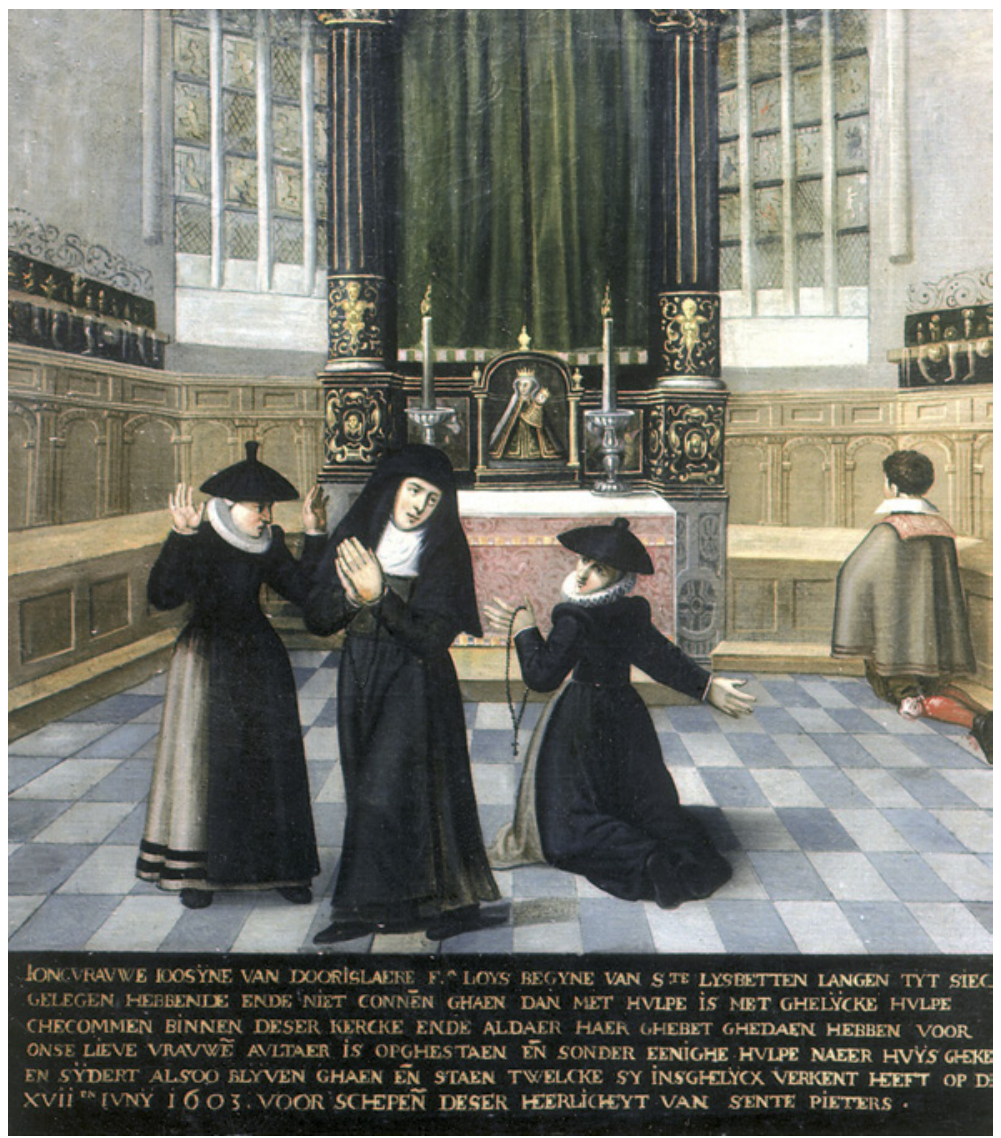

Counter-Reformation proceeded during this period? The successful Spanish reconquista of 1585 signaled the start of a careful restoration, not only in a material sense, but also in terms of ecclesiastical organization and Catholic piety. ${ }^{25}$ In recent years, historians have shown that this was a highly interactive process rather than a unilateral top-down reform. ${ }^{26}$ However, what was the role of local shrines and their churchwardens in this process?

\section{A New Era?}

Soon after the Beeldenstorm had hit shrines all over the Low Countries, a Protestant song circulated in which the end of an era was proclaimed. It opened with a question which immediately set the tone: 'How have the times changed? Many saints are not honored anymore in these Flemish fields'. The remainder of the song 
provides an invaluable catalogue of Netherlandish cult sites, until it suddenly pinpoints the core of the alteration: 'All these saints have submerged, they do not work miracles anymore. ${ }^{27}$ Evidently, the text referred to the scale and efficacy of the 1566 iconoclastic cleansings, which many Protestants - including Philips of Marnix, Lord of Saint-Aldegonde - initially regarded as proof of the legitimacy of their cause. ${ }^{28}$ This idea of an age that had come to its end in 1566 was widespread. It is clearly reflected in miracle collections (Chapter 4), and is also expressed in an anonymous print depicting an allegory of the Beeldenstorm (fig. 136). In the background on the right side of this image, we see a group of iconoclasts pulling down a statue above a church portal, and hammering on others which are already on the ground. In the foreground, men in typical Geuzen costumes symbolically clean up the Catholic debris using brooms. The positive, Christian connotation of these actions is emphasized by the inclusion of a group of clergymen kneeling and praying in front of an altar on which the Pope is depicted as the Whore of Babylon riding the seven-headed beast. Hence, through their actions, the iconoclasts revealed once and for all the falsehood of the Church of Rome, whose members served the Antichrist. The accompanying captions still convey this early sense of euphoria which characterized the immediate aftermath of the Beeldenstorm, which means that the print was probably published soon afterwards. It attributes

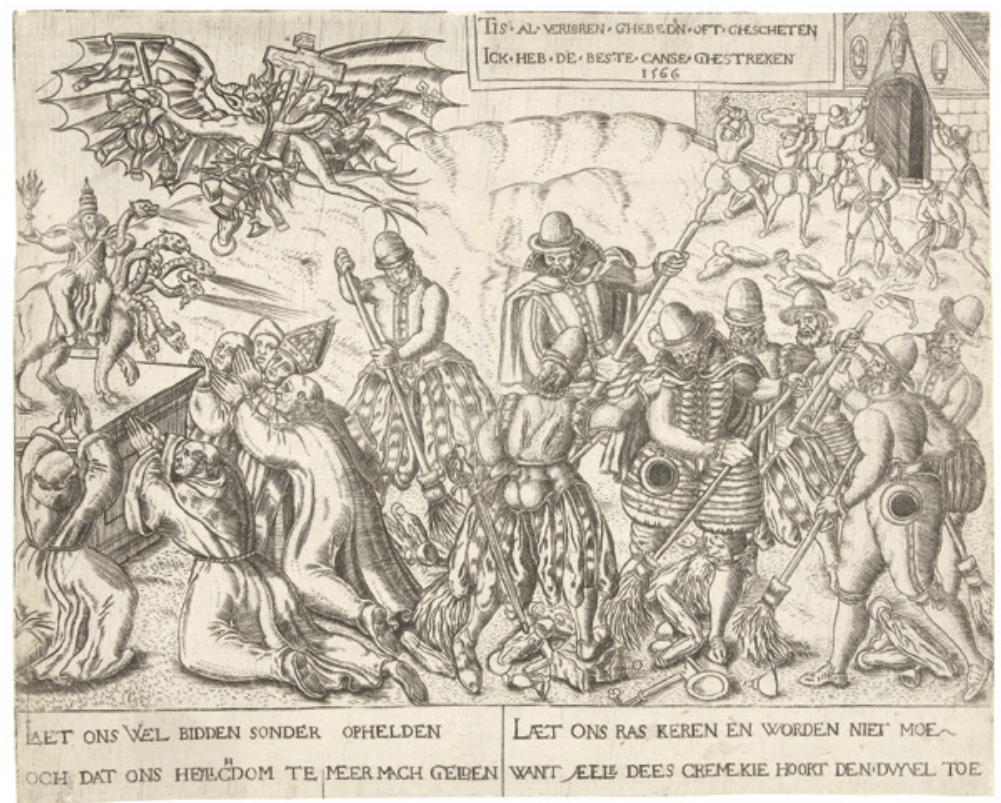

FIGURE 136

Anonymous, Allegory of

the Beeldenstorm, 1566,

Amsterdam, Rijksmuseum 
the swept-up Catholic material culture ('this peddlery') to the Devil, who is depicted above, flying off with a number of ornaments he was able to save. In a caption next to him, he admits his defeat, stating that his time is over and done. The explicit addition of the year 1566 leaves no doubt about the date of this definitive turning point of the Church of Rome's supremacy. ${ }^{29}$

In accordance with the Protestant conviction of the cessation of miracles after the apostolic age (Chapter 4), the theorists of the Reformation held the Devil responsible for the miracles which had been so vital for Catholic culture and devotional life during the preceding decades. Both the song and the print that appeared after the Beeldenstorm accentuated the topicality of the Protestants' theoretical conviction: the Devil flew off and miracles stopped occurring. These religious debates and upheavals had a profound impact on devotional life, since around mid-century, there was almost no shrine left that still recorded miracles, as if they had actually ceased in accordance with the Protestant doctrine. When the most violent period of the conflict temporarily calmed down around 1600 however, the Catholic Church started picking up the pieces. But it faced a major problem: how to account for the apparent lack of miracles during the middle of the sixteenth century?

\section{Explaining Intermittency, Asserting Continuity}

Even in Zoutleeuw, 1566 had pernicious consequences for the devotional fabric, regardless of the town's demonstrable tenacity and its continuity of traditional religious practices. Remarks by contemporary authors on the dearth of tangible material on miracles make it clear that this is not a mere misinterpretation by modern historians caused by fragmentarily preserved sources. In his account of the miracles at the shrine of Our Lady of the Ossenweg from 1632, Augustinus Wichmans uttered a general complaint. He found traces of only eighteen authenticated miracles, in the original parchment miracle book and in unspecified 'proofs' (argumenta) of healings hanging in the chapel. He concluded that it was regrettable that not all miracles had been recorded, 'just as it is the case in so many other holy places'. According to him, this was the result of negligence, but even more so of carelessness and ingratitude on the part of those who had received the benefaction. ${ }^{30}$

One of the 'many other holy places' Wichmans referred to was the shrine of Our Lady of Halle. Justus Lipsius published his famous treatise Diva Virgo Hallensis on this cult in 1604, the lion's share of which was based on a copy of the church's miracle register. ${ }^{31}$ Towards the 
end of his text Lipsius noted that most of the miracles he had talked about so far were all dated between 1400 and 1500 , adding that 'from that point onwards until our time, there is a silence'. This observation corresponds to an actual hiatus in the original manuscript that has been preserved in Halle. ${ }^{32}$ Even though he was able to collect evidence of nine miracles between 1535 and 16o3, these were not written down in the acts, but rather 'described or depicted on votive tablets'. Thus, 'contrary to what is claimed by some', Lipsius maintained that 'memorable events did actually happen in our time'. As an explanation for the lack of evidence, the author concluded that the people responsible for the registration of miracles must have judged Our Lady of Halle's fame sufficiently spread by their time, and therefore did not deem it necessary to add new miracles to the list. ${ }^{33}$ Both authors thus maintained that there had definitely not been a cessation of miracles, and explained the lack of evidence by claiming that they were simply not duly recorded.

Lipsius and Wichmans are among the best-known reporters on seventeenth-century miracle cults, but their publications were preceded by Cornelius Columbanus Vrancx' Den tweeden cout der nichten (16oo). Written in the vernacular, this was a very popular book and was arguably even more ambitious than Lipsius and Wichmans' publications: it contained an overview of 23 Marian shrines in the southern Low Countries (Artois, Brabant, Cambrésis, Flanders and Hainaut) and elsewhere in Europe (Italy, Portugal and Spain). By the time of its publication, Vrancx (d. 1615) was a well-known and successful preacher and a prolific author, mostly of anti-Calvinist treatises defending Catholic tenets such as the Eucharist or Our Lady. In 1597, he was elected abbot of the Ghent abbey of Saint Peter, and it was in this capacity that he published Den tweeden cout. ${ }^{34}$ The book is a sequel to a first dialogue (cout) on the life and the virtues of Mary, which he had published the year before. In the second dialogue that constitutes Den tweeden cout, the two devout women, Margriete and Willemyne, each recount a series of miracle narratives, organized according to cult center.

Vrancx' intentions were essentially practical, and his primary purpose was to demonstrate the existence of miracles. Like Lipsius and Wichmans, he admits that the evidence is rather limited for the middle of the sixteenth century, and at one point he explicitly attributes this to the rise of Protestantism. The occurrence of miracles had always been a custom (ghewoonte), but 'due to the heresy of Luther and others who scorn the holy saints, this tradition has disappeared'. ${ }^{35}$ In part, he circumvented this lack of evidence 
by referring to foreign cult centers - including Guadalupe, Loreto, Mondovì and Montserrat - which he then subtly linked to the Low Countries by showing that the thaumaturgic images venerated at these places had been successfully invoked by Netherlanders throughout the sixteenth century. ${ }^{36}$ Yet, like Lipsius, he also emphasized that the thaumaturgic powers of Our Lady and the saints had never disappeared from the Low Countries. In fact, 'miracles would happen daily, if she [Our Lady] were invoked daily'. ${ }^{37}$ It is in this precise context that Vrancx' book was supposed to be helpful:

MARGRIETE: This habit needs to recover.

WILLEMYNE: By the hearing or reading of these miracles it will doubtlessly be done, and the poor peasant will often find comfort in Mary (...)

MARGRIETE: I think that the parish priests who read and know these miracles will please their community by preaching and joyfully proclaiming them.

WILLEMYNE: That's why all parish priests need to know these miracles. ${ }^{38}$

In particular, the actual 'miracles that still occur at various places within the holy Catholic Church need not be concealed, because it is profitable to know them in these pitiful times of the last century, during which so many people have fallen into disbelief and various heresies, and still fall at many places'. ${ }^{39}$ In other words, by informing the laity about miracles that have happened both in the past and in more recent years, thus emphasizing the unabated thaumaturgic powers of Our Lady and the saints, Vrancx was convinced that the people's devotion would again increase, which in turn would restore continuity with the pre-Reformation era.

\section{Cultic Antiquarianism}

For this reason, Vrancx wanted to collect source material that risked getting lost. The most acute threats were of course the ongoing war and the ruthless behavior of the Geuzen. For instance, in his discussion of Our Lady of Hanswijk, he stated that a lot of miracles had been recorded in a parchment book, 'which was found and broken by the Geuzen, out of the hatred they bear towards God, his sweet Mother and all the Saints'. ${ }^{40}$ Carelessness in registration was equally problematic. For instance, Vrancx observed that in the chapel devoted to the Mother of God in his own abbey church a great many wax ex-votos testified to the thaumaturgic powers and popularity of the 
statue (fig. 135). However, he is unable to recount a single event, since nothing had been written down - something which was beyond his comprehension. ${ }^{41}$ In order to remedy this situation of imminent loss, Vrancx industriously set out to collect as much evidence as possible, and he appears to have conducted ample research. In most cases, his sources consisted of written or printed miracle books, but his quest also benefited from material sources such as memorial or votive tablets which decorated the walls of the churches and chapels he had visited. In Tongre-Notre-Dame (Hainaut) he obtained his information from old churchwarden accounts, and in other cases he refers to sermons in which miraculous stories had been recounted. ${ }^{42}$

Such antiquarian concerns are characteristic for this period. ${ }^{43}$ For instance, when Peeter Spijskens was appointed parish priest of the church of Our Lady in Tielt (Brabant) in 1596, he immediately set out to collect as much material as possible on the miracles worked by the miraculous statue of the Virgin that was venerated there. However, the ravages of war had wiped away many traces, and the earliest miracle he was able to reveal only dated from $1572 .{ }^{44}$ Other cult centers, on the other hand, could boast proof of medieval miracles. As a result, such investigations - meant to demonstrate continuity - led to a recurring pattern of adding new miracles to medieval collections after a long, sixteenth-century hiatus. The clearest example provided by Vrancx is the series of stories from the Marian shrine at Tongre-Notre-Dame. No miracle book is mentioned, but the Ghent abbot compiled a selection with the help of 'antiquities and old accounts from the church'. On a total of 29 stories, 25 are dated between 1081 and 1497, to which four were added that occurred between 1591 and 1598.45 The same tendency can also be discerned in collections that were not included in Den tweeden cout. An interesting example is the case of Our Lady of Dadizele, of which the miracle collection consists of 26 stories dating from 1353 to 1537 . One final example of 1617 was added to this collection, as 'demonstration that Gods hand was not curtailed'. 66 The same can be seen in the collection related to Saint Alena from Vorst, where the thread was picked up in 1602 after a hiatus from 1527 onwards, and in the substantial book of Our Lady of 's-Hertogenbosch, of which all recorded miracles date from before 1521 , with the exception of one from $16 \circ 3 \cdot{ }^{47}$

Vernacular, devotional treatises on individual shrines, published around 1600 , similarly deployed this discourse of emphatic restoration of tradition in order to strengthen their individual legitimacy. ${ }^{48}$ Almost without exception, these publications gave historical overviews of the cults, tracing back their origins to a distant past in order 
to refute Protestant accusations of being invented only recently. Etienne Ydens' book from 1605 on the Holy Sacrament of Miracle in Brussels is a clear case in point. After having recounted the history and the miracles of the cult by means of the findings of his extensive research in churchwarden accounts, official testimonies and various sorts of gifts, Ydens directly addresses the reader:

Catholic reader, by the extracts transcribed above and by the narration of so many sufficiently verified miracles, one can clearly recognize how great and shameless the impudence of the heretics of our time is, and in particular of those who had kept our city of Brussels and dared to publish a placard in 1581 , in which they - among many other blasphemies, calumnies and impostures - claimed that this Holy Sacrament has only appeared for the first time in 1529 during the disease called the sweating sickness (...) And yet by the same placard they cannot conceal that more than hundred years before people already talked about it. ${ }^{49}$

The rich documentation he provided in his treatise thus was not only meant to arouse enthusiasm for the city's Eucharistic relics, but also to dismiss the very specific rumors of denial that had been spread during the Brussels Calvinist regime (1577-1585). These rumors were launched with the sole purpose of unmasking the relic as a recent invention that had nothing to do with the true, apostolic faith. On the contrary, Ydens tried to show that the cult was already there well before Protestant ideas started to spread, and that it was part of an established Christian tradition. Yet, the simultaneous existence of these two disparate visions is a striking example of opposing, contemporary interpretations of the cyclical movements of cults (Chapter 3 ): the Brussels cult definitely had fourteenth-century origins, but it was indeed actively revived from 1529 onwards under the impulse of the Habsburg Court, arguably to counter Protestant critiques (Chapter 4).

\section{The Rise of Votive Paintings}

Often confronted by a lack of written records, Catholic authors around 1600 increasingly turned to votive paintings as a source to establish the miraculous continuity of Netherlandish shrines. One of the sixteenth-century miracles Ydens was able to collect was 
documented on a panel he had seen. It recounted how, in 1536, a certain Lauren Couderlier, courtier and garde de linge to Emperor Charles v, was dangerously ill and called upon the Brussels Holy Sacrament of Miracle. It reportedly 'appeared to him in a vision, in the same way as it can be seen in said church [Saints Michael and Gudula]'. He recovered, and 'in memory of this great benefice and as an act of grace, he had a panel painted, representing said vision and carrying a subscription of this beautiful miracle., ${ }^{50}$ Vrancx too made use of this particular type of material source. In his discussion of Notre Dame de la Fontaine at Chièvres, for instance, he includes the story of a man who had been tormented by extreme pain for 21 years, but was miraculously cured after a pilgrimage. In gratitude (in danckbaerheyt) for this miracle he had a painting (tafereel) made and sent to the shrine. ${ }^{51}$ Similarly, Wichmans mentions a painting (tabulam) which included a representation of how a child was miraculously cured through the intercession of the statue of Our Lady in the church of Saints Michael and Gudula in Brussels. In this case, the panel was donated by the parents 'as testimony to their gratitude for the received benefaction, 52 All these panels are now lost, but functionally and formally their descriptions fully correspond to the definition of votive paintings: given in grace by the votary, and documenting the miracle in word and image.

The pictorial genre was mentioned in passing by Molanus in his treatise from 1570 on sacred images, while discussing other votive offerings, the giving of which he described as an ancient custom. ${ }^{53}$ Donating wax or metal figurines to shrines had indeed been customary since the early and high Middle Ages, but votive paintings on the other hand are only documented in Europe from the later fifteenth century onwards. Quasi-continuous series from around 1500 until the present have been preserved in Spain and, more extensively, in Italy, where we know of more than 1,5 oo paintings from the fifteenth and sixteenth centuries. The earliest extant and documented examples from Germany and Austria also date from around 1500. In these regions, the practice came to a temporary standstill with the Reformation, only to become almost a mass phenomenon in the 1620 s and 163 os, parallel to the revival of old shrines and the foundation of new ones. ${ }^{54}$ In the Low Countries, not a single votive painting dating from the fifteenth or sixteenth centuries has been preserved, and the genre has been neglected in scholarly research. Yet, scrutinizing the available evidence provides us with important insights into the evolving dynamics of miracle cults. ${ }^{55}$ 
Contrary to what Molanus' discussion suggests, votive paintings were a relatively new phenomenon in the Low Countries when he wrote his treatise. Molanus himself does not give specific examples, and the ones mentioned by Vrancx, Lipsius and Wichmans are often undated. ${ }^{56}$ Yet, the evidence suggests that they only appeared during the middle of the sixteenth century. Lipsius only mentions examples from 1535 onwards, and Ydens' example from 1536 likewise seems to have been among the earliest. ${ }^{57}$ Furthermore, the absence of unequivocal terminology throughout the sixteenth century might be a sign that the practice was not yet well disseminated. Lipsius, who was well-travelled, was the first author in the Low Countries to use precise vocabulary in his book from 1604 on Our Lady of Halle. When describing the statue's chapel, he mentioned that it was 'decorated with offerings and votive panels (tabulis votivis). ${ }^{58}$ While the very same panels had been mockingly referred to as tafereelkens by Philips of Marnix, Lord of Saint-Aldegonde, in 1569, two Dutch translations of Lipsius' text, published in 1605 (Delft) and 1607 (Brussels) respectively, demonstrate that there was still no Dutch equivalent. ${ }^{59}$ The - Protestant - translation from Delft interpreted Lipsius' concise term tabulis votivis either literally as 'promised panels' or as 'panels that were given out of devotion', whereas in the other version, the term was elaborately translated as 'panels that were given in memory of miracles and received benefactions. ${ }^{60}$

The relative scarcity of examples makes it difficult to make any definitive claims about the actual dissemination of the practice of donating votive paintings in the Low Countries, but the evidence at hand suggests that it only started well into the later sixteenth century, and that it increased in popularity after 1600 . For instance, at the pilgrimage church of Our Lady of Alsemberg, some eight examples dating between 1611 and 1682 have been recorded in the church's archives. The first was donated by Pieter van der Haegen, meier of Alsemberg, in gratitude for his sudden recovery. In this votive panel, Van der Haegen was said to have been represented kneeling before Our Lady ${ }^{61}$ A comparison between two prints that show the interior of Our Lady's chapel in Halle, from 1604 and 1658 respectively, further confirms this increase in popularity during the course of the first half of the seventeenth century. This important Marian pilgrimage destination housed a miraculous statue of the Virgin and child since at least the thirteenth century, and its chapel was filled with many costly gifts, several of which were donated by prominent 
people, among which the Dukes of Burgundy. ${ }^{62}$ However, while the print from 1604 that was included in Lipsius' Diva Virgo Hallensis only shows one or possibly two votive paintings, this number increased to at least 10 in the print from 1658 , visible on the right wall (figs. 137 $\& 138)$. One of these, the one hanging in the doorway on the lower right of the print (p. 258), is still extant, making it one of the earliest preserved examples in the Low Countries (fig. 139). The panel from 1614 depicts wealthy silk merchant from Antwerp Rogier Clarisse (d. 1622), who was part of a network of friends that included Lipsius. Clarisse is shown kneeling in front of Our Lady, who is shown amidst an enlightened group of clouds, through whose intercession he had recovered from health, as explained by an inscription on a banderole in the lower right corner. ${ }^{63}$

This chronological evolution in the Low Countries corresponds to Willem Frijhoff's observation that the practice of giving votive paintings spread across Europe in close connection with the Counter-Reformation, even when taken in its literal sense as countering Protestantism (Chapter 6). ${ }^{64}$ The social profiles of the donors indeed fit the observed prominence of local elites in early reactions on Protestant critiques: Couderlier was a courtier, Van der Haegen was a meier, Clarisse was a wealthy merchant and, judging by his clothing and coat of arms, Walschatten in Jezus-Eik (fig. 129) must also have been among the better-off. And while the early example (from 1536) from Brussels might at first sight seem to contradict Frijhoff's hypothesis, it is crucial to emphasize that the revival of the whole cult of the Holy Sacrament of Miracle was in fact a direct reaction to Protestant developments, and a refutation of increasing critique (Chapter 4). The Habsburg court was particularly involved, and in this respect it is all the more interesting that the votive panel in question was donated by a courtier of Charles v. Regardless of whether these paintings were a genuine expression of piety and gratitude, a reaction against critique, or indeed a combination of both, the visual representation of the miracle combined with its textual elucidation must have served as a clear and readily understandable argument in ongoing discussions in the Low Countries. In a highly effective way, such images argued in favor of both the Real Presence and of the existence of miracles. As objects they were particularly suitable for a Catholic counteroffensive, and Wichmans certainly had had good reasons to later refer to similar paintings as argumenta. ${ }^{65}$ 

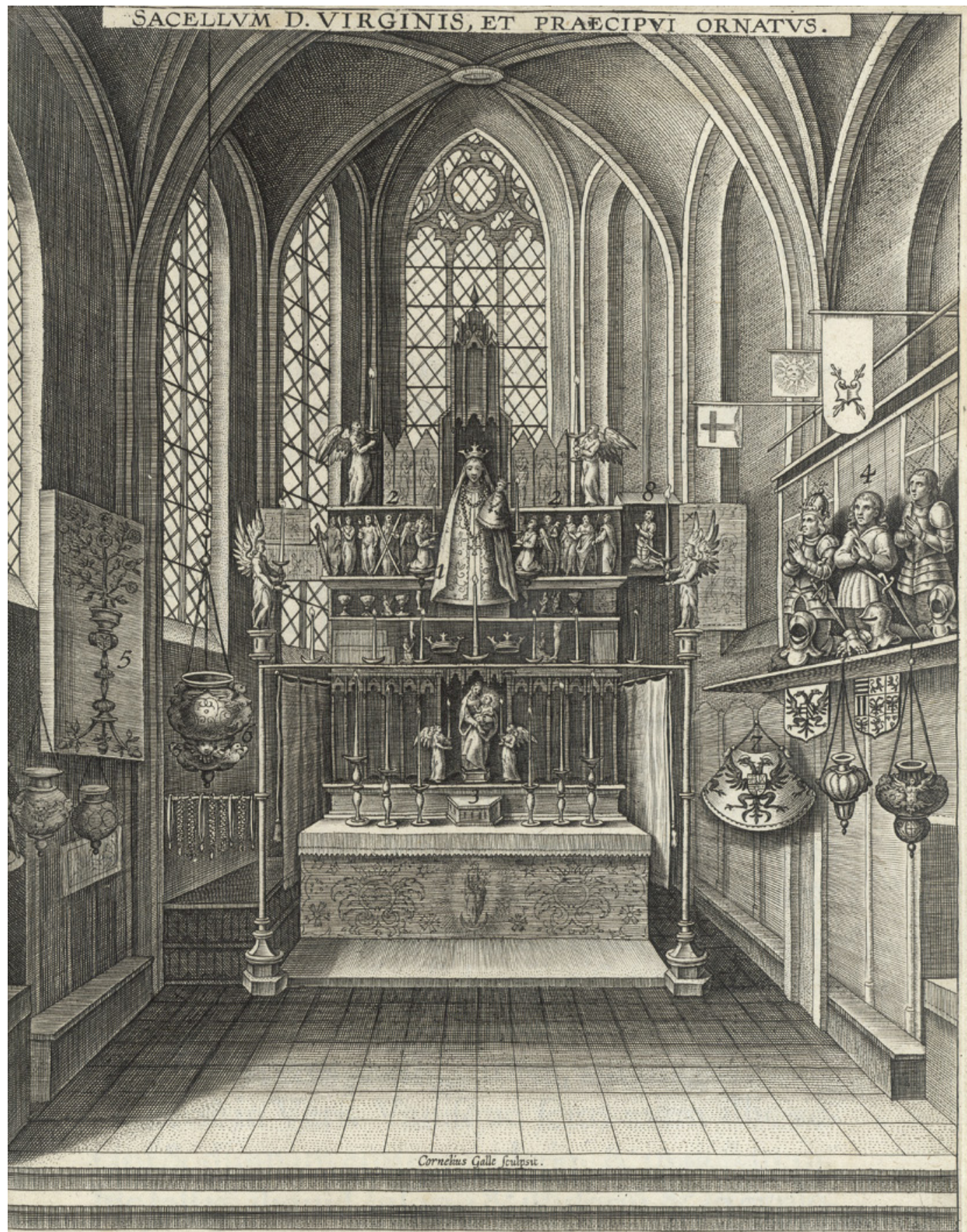

\begin{tabular}{|c|}
\hline 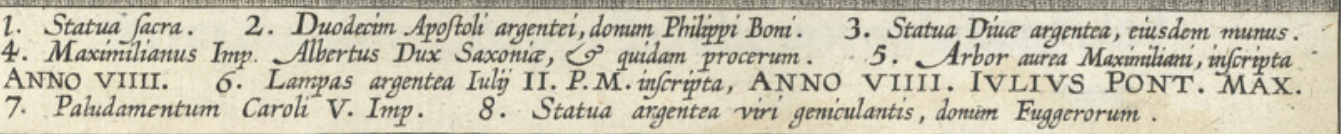 \\
\hline
\end{tabular}

FIGURE 137 Cornelis Galle, The chapel of Our Lady of Halle, from Lipsius 1604, Ghent, University Library 


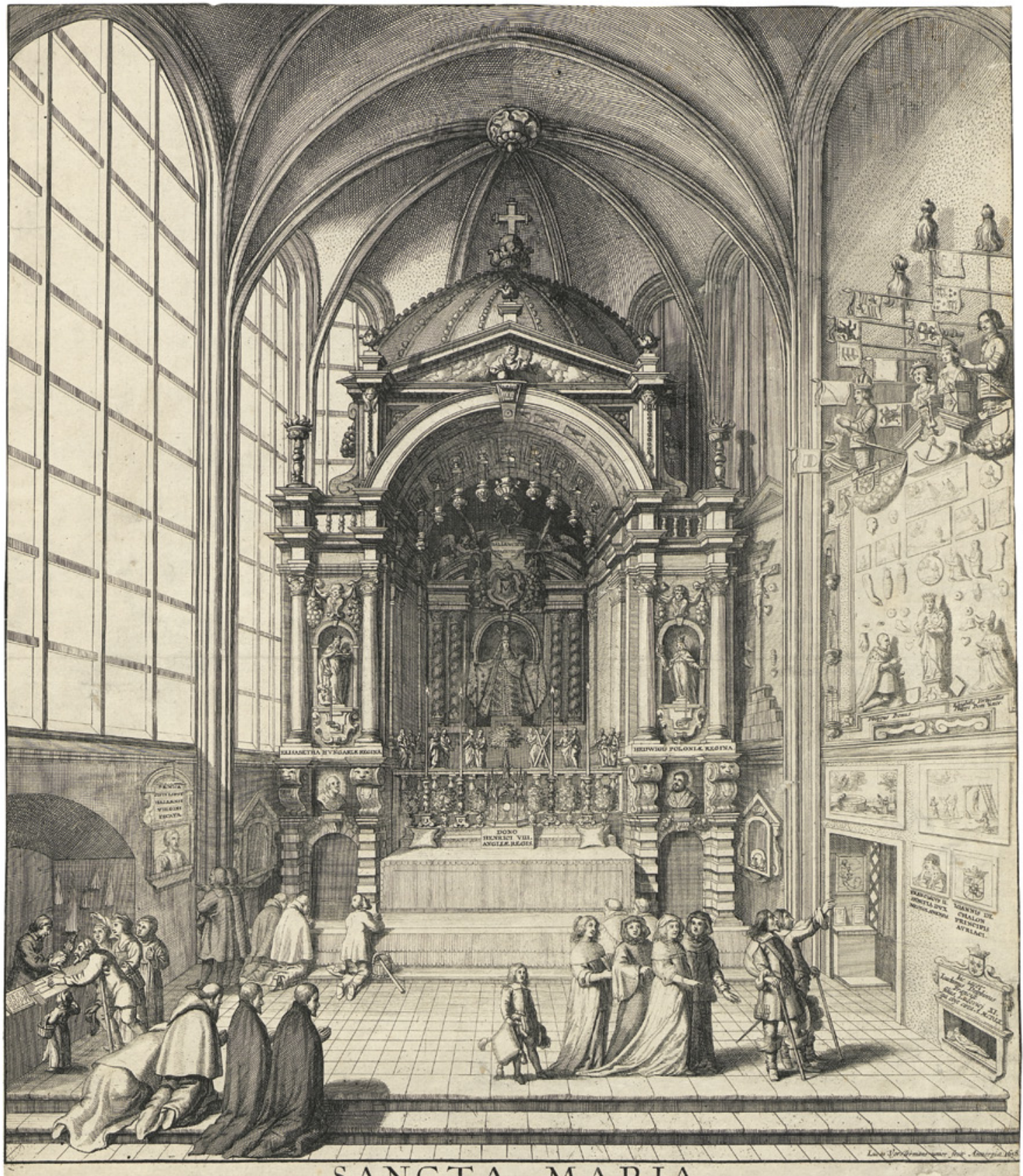

\section{SANCTA MARIA}

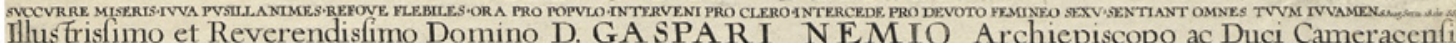

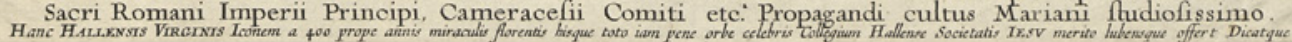

FIGURE 138 Lucas II Vorsterman, The chapel of Our Lady of Halle, 1658, Brussels, KBR 


\section{FIGURE 139}

Anonymous, Votive painting of Rogier Clarisse, 1614, Halle, basilica of Saint Martin PHOTO: JAN DEMOL

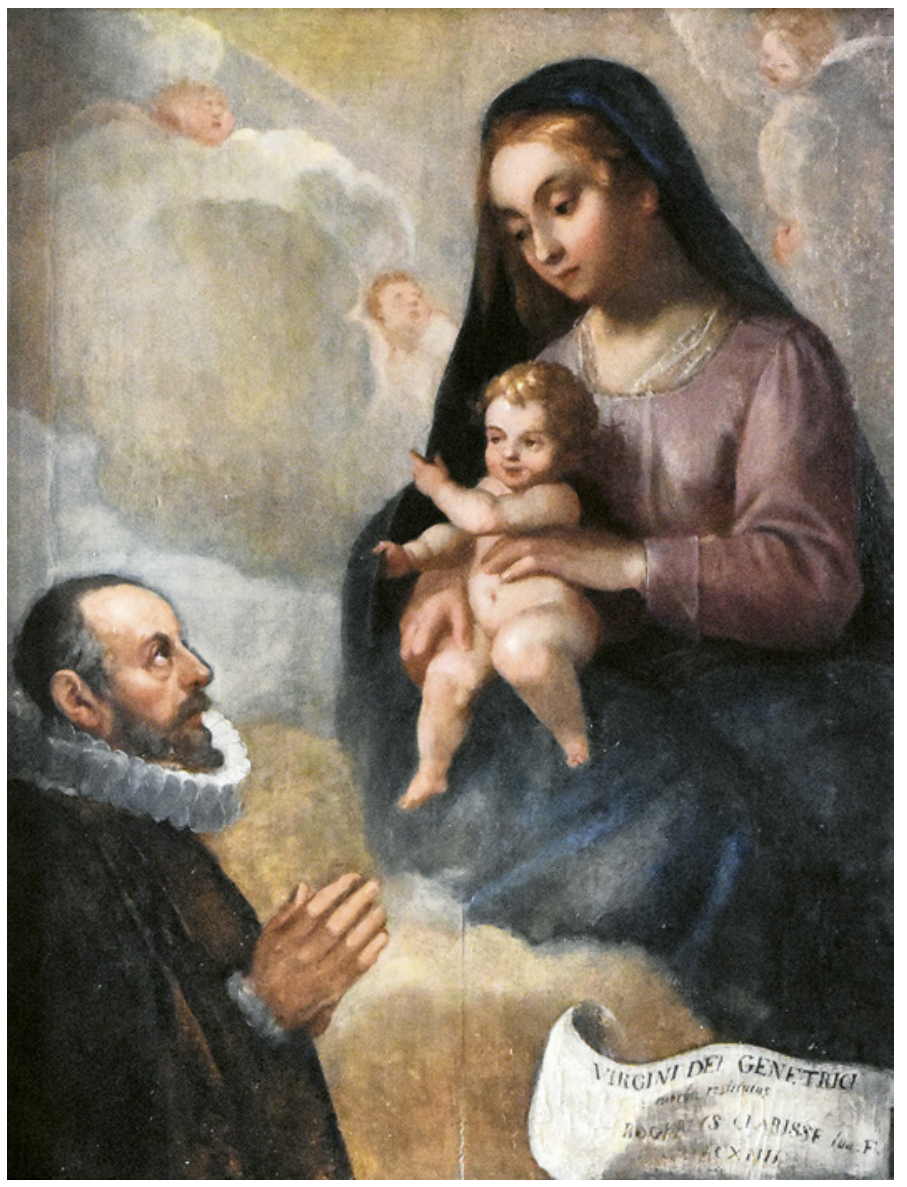

\section{A Culture of the Miraculous}

The rise of this new type of devotional objects around 1600 is illustrative of the fresh dynamics and renewed popularity of miracle cults. The material assembled by Vrancx in his publication from 160o confirms this development, and he was convinced that his book - and communication on miracles in general - would greatly contribute to this trend. His Jesuit colleague Franciscus Costerus (1532-1619) - an equally popular preacher and prolific publicist similarly recommended his audience in 1604 to go on a pilgrimage from time to time 'because one observes that at saints' shrines miracles do actually happen'.66 Quantitative analysis supports this observation: the number of shrines where miracles were recorded increased again (graphs 10 \& 11), charting the initially slow but subsequently impressive revival of devotional activities at established 
cult centers in the Low Countries at the dawn of the seventeenth century. The prevailing climate has aptly been dubbed 'miraculous' by Henri Platelle, who, while studying seventeenth-century Lille and its surroundings, noticed a steady rise of newly originating devotions and shrines, where all of a sudden new series of miracles started to occur. ${ }^{67}$

This miraculous revival was subtly notable at the already existing shrines, but much more significantly so in the newly established ones. Platelle rightly emphasized the important 'role of newness'. ${ }^{68}$ Just like a century before, the Low Countries saw a steady rise in new cult centers, mostly devoted to the Virgin Mary. The bestknown is certainly Scherpenheuvel, where - not unlike Our Lady of the Ossenweg - a small statuette hanging on an oak had started to work miracles in the last decades of the sixteenth century. In 16oo, Vrancx did not yet include it in his overview of Marian shrines in the Low Countries, but it would very soon become a place of 'national' importance. Its fame spread quickly, and in 1602 a wooden chapel was built to accommodate the increasing flow of pilgrims. The most important impulse was given the very next year, when Habsburg Archdukes Albert and Isabella started to engage with the new shrine. They attributed the successful outcome of the siege of 's-Hertogenbosch in 1603 to Our Lady of Scherpenheuvel, which marked the start of a lifelong devotion to the cult statue and an extensive patronage project that would develop the initially small place into a veritable Marian town, which could boast the first church with a cupola in the Low Countries. ${ }^{69}$

The increasing dynamics led Mathias Hovius, Archbishop of Mechelen, to commission an investigation into many of the miracles that were said to have happened there. The task was carried out by Philips Numan, a town clerk from Brussels, and soon afterwards, Hovius gave official consent to have the rich collection published. Numan's Historie vande mirakelen came out in the summer of 1604 and contained a set of 63 endorsed stories, 46 of which were dated to $16 \circ 3$, and 14 to the first months of 1604 , just prior to the book's publication. Like Vrancx and other authors, Numan also assessed the popularity of the shrine in terms of ex-votos. In 16o3, 135 crutches were reportedly displayed in the chapel, in addition to a great amount of shoes, clothes and wax or metal figurines. Furthermore, there was also a selection of more prestigious gifts, including a silver crown from the city of Brussels, two silver chandeliers from the city of Antwerp, an antependium from Dorothea of Lorraine, and several gifts from the archdukes and members of their court. In 1613, 
Numan edited a first continuation, and a second one would follow in 1617 . A total of 266 different miracles would be published between 1603 and 1682, but their chronological distribution was clearly concentrated in the earliest years: more than one fourth (73) was dated between 1603 and 1605 , and more than two thirds (187) between 1603 and $1633 \cdot{ }^{70}$

The practice of pilgrimage and the belief in miracles had taken on a strong confessional character. Some examples from the middle of the sixteenth century already suggest this tendency (see Chapter 4), but around 1600 it was explicitly acknowledged in Catholic writings. Vrancx was convinced of the merits of publishing miracle stories: they would strengthen the people in their Catholic faith. Similarly, Costerus claimed that miracles confirm believers in their religion. Collectively, these publications were intended to create a shared, Catholic identity among the inhabitants of the southern provinces. ${ }^{71}$ The fact that official but unpublished documents use the very same discourse illustrates the general dissemination of the idea. For instance, the document drawn up by the Ghent aldermen, which testified to the previously mentioned miracle from 1603 (fig. 135), explicitly stated that it had been drawn up lest everyone should be strengthened in the faith and the power of God and his blessed mother, and do not doubt it. ${ }^{72}$ Unsurprisingly, for the great majority of the faithful, such wonderful events indeed counted as the most important parameters for the efficacy of the saints.

Strengthening one's faith is one thing, disproving the validity of the Reformation another. Simon Ditchfield has noted how, after the Council of Trent, miracles came to play a central role in the Catholic Church's argumentation for its position as the one true church. ${ }^{73}$ In the Low Countries, this idea also spread among the flock by means of vernacular publications such as Cunerus Petri's Den schilt teghen die wederdoopers (1568) and Costerus' Schildt der catholijcken teghen de ketterijen (1591) - two prime examples of books that were explicitly meant to furnish Catholics with the necessary readymade arguments to retort Protestant charges to the accusers. ${ }^{74}$ Miracles were particularly promoted by the Jesuits, of whom Costerus was a central figure around ${ }_{1600}{ }^{75} \mathrm{He}$ argued that Catholics continued to believe in miracles, since they are signs of the holiness of the venerated objects and proof of the truth of Catholics' faith. Citing Christ from the Gospels (John 15, 24), he established that new faith (nieuw leeringe) always needs miracles to prove its validity. Yet, while this clearly does not happen to endorse Protestant doctrine, many miracles still occur within the Catholic Church, which demonstrates 
anew the truth of their belief. ${ }^{76}$ Miracles were thus considered as proof that the Catholic Church controlled the supernatural realm, and hence also of its position as the one true Church. As a result, going on a pilgrimage and believing in miracles were not only considered as a refutation of Protestant doctrine, but also as an open confirmation of orthodoxy. Hence, Costerus actively encouraged believers to go on pilgrimage, and at the same time pre-empted oftheard criticisms of the practice. While it was often criticized as an immoral activity that lead participants to engage in lascivious behavior in far-away places while their families remained unprotected at home (Chapter 4), Costerus particularly emphasized the importance of nearby shrines. ${ }^{77}$ This indeed become custom, which created renewed opportunities for regional shrines such as Zoutleeuw. ${ }^{78}$

While Costerus saw in the miraculous climate circa 16 oo a confirmation of orthodoxy, other writers even posited a direct causal connection between Protestant reproaches and the increase of miracles. Lipsius, for example, claimed that the saints, and especially the Holy Virgin, work so many miracles in these times, precisely because they are being refuted by the heretics. ${ }^{79}$ Just as in the mid-sixteenth century, miracles were still seen as anti-Protestant revelations. ${ }^{80}$ The clearest illustration is a particular category of miracles in which Protestants actually played a part. In 1598, Jan Coens made use of these as a rhetorical strategy in his confutation of Philips of Marnix' De bienkorf der h. Roomsche kercke (1569), one of the most stinging and most popular critiques of the practices of the Church of Rome. As Marnix had employed Our Lady of Halle to make his point, Coens used the same shrine to enforce his arguments. ${ }^{81}$ Among the many miracles, he singled out two stories from 1582, when the Geuzen tried to capture the city. Not only had the statue of Our Lady successfully defended her stronghold Halle, but through her intervention, her assailants were also suitably penalized: a heretical churchwarden who had boasted that he would sell the thaumaturgic statue was turned into a fearful swineherd, and the soldier who had planned to cut off her nose was deprived of his own by means of a bullet. ${ }^{82}$ Coens included similar stories on other cities and their images, where they were linked with episodes of iconoclasm. When in 1566 an iconoclast in 's-Hertogenbosch defied an image of Saint Anthony - a saint who had given his name to ergotism, known as Saint Anthony's fire - to show off his power, the man was instantaneously struck by the disease and died. A similar fate befell a man in Bruges, who had mocked Saint Christopher by climbing on the shoulders of the statue, saying that he had carried the Christ child long enough and 
that it was his turn now. ${ }^{83}$ The carnivalesque inversions that were so typical of iconoclasm clearly did not go unpunished.

Earlier examples from the 153 os show that there were definitely antecedents (Chapter 4), but now the thorny memories of recent iconoclastic events were systematically forged into arguments in favor of Catholic supremacy. ${ }^{84}$ Coens was by no means the only author in late-sixteenth-century Brabant to do so, and the fact that similar miracles also occurred in unpublished acts is illustrative of the degree to which such ideas prospered in Catholic communities. In Everberg, for instance, all original documents attesting to the miracles worked by the locally venerated Holy Cross got lost in the troubles, but in 1588 , the local confraternity recorded the testimonies of prominent inhabitants. In this small collection of collectively remembered miracles was a story of a group of Geuzen who unsuccessfully tried to take away and burn the Cross and the images in the church, after which they themselves caught fire. ${ }^{85}$ This particular category of wonders was also visualized in miracle memorial paintings. One example, preserved in Vilvoorde, depicts an event in 1578 , when the Geuzen attacked the local beguinage, where the miraculous statue of Our Lady Ten Troost was venerated. However, the statue was saved, and reportedly pushed the assailants from their ladders. Interestingly enough, the painting was probably commissioned around 1586, and carried in the procession for Our Lady Ten Troost that took place after the Calvinists had been driven out. 86

Precisely because of this heightened importance of miracles as crucial arguments for Catholic orthodoxy, the Church also sought to establish greater control over them. The ecclesiastical authorities now adopted a notably more critical stance, and consequently invested much time and effort into verifying whether the miracles that were reported everywhere were genuine manifestations of the divine, and not human or devilish fraud. As this had been a central Protestant critique of the Catholic Church, Rome evidently wanted to prevent abuse in order to smother all potential critiques in advance. The Tridentine decrees on the cult of saints had stipulated that 'no new miracles [were to] be accepted (...) unless they have been investigated and approved by the same bishop'. Thus, if a local shrine wanted to take advantage of a miraculous intervention by having it pronounced in sermons or published in booklets, they were now obliged to have their miracles officially approved by following a fixed procedure which usually cost a significant sum of money. A dossier with testimonies by the miraculé and witnesses, sometimes 
supplemented by a doctor's certificate, had to be handed over to the bishop, who appointed an ad hoc committee of inquiry. This committee then sent a report with their findings back to the bishop, who took the final decision on the matter. ${ }^{87}$

Such a critical attitude was already adopted soon after the Beeldenstorm. An early case of suspected fraud has been documented in Merchtem, a village northwest of Brussels. In January 1569, the church was attacked by iconoclasts, who broke open the sacrament house and threw the consecrated hosts on the ground. They were reportedly picked up by the parish priest the very next day, who noticed red stains on them, which he believed to be blood. In March, the priest eventually decided to show these alleged Eucharistic relics to Maximilien Morillon, whose suspicion was aroused immediately. Morillon based his decision on his familiarity with the art of painting, claimed that the color was in fact artificial, and set up an investigation. ${ }^{88}$ Although the priest and the local lord's insistent request to have the miracle pronounced was not granted, they nevertheless proclaimed the news with solemn celebrations and a procession. Evidently, this only aggravated the conflict, and the whole issue was presented to theologians in Leuven. In June, the commission finally debunked the whole story as a fraud and indeed identified the blood as an artificial color. The priest was sanctioned. ${ }^{89}$ A similar story is known in Breda. In September 1580 , the local Augustinian nuns displayed two crucifixes and an Ecce Homo statue in their convent chapel, which reportedly sweated blood. People were already giving monetary offerings, but an investigation was set up and it was soon revealed that the sextoness had covered them in blood herself. 90

The treatises on shrines and their miracles, published around 16oo, similarly display a heightened sense of source criticism. Lipsius, for instance, assured his readers that he wrote his Diva Virgo Hallensis as a historian rather than as a theologian, and before narrating Our Lady's miracles, he devotes a whole chapter to a discussion on how to discriminate between genuine and false cases. ${ }^{91}$ Other examples also testify to the role and importance of original documents and images displayed in cult centers as proof of miracles. Printed miracle books increasingly included word-for-word transcriptions of the original notary depositions, sometimes even graphically imitating the documents' signatures - a phenomenon Benz aptly referred to as creating an 'atmosphere of historicity'. ${ }^{22}$ As will be demonstrated, the miracle memorial painting from Zoutleeuw is a variation on this very theme. 


\section{Zoutleeuw, 1612}

Just like so many others, the cult of Saint Leonard in Zoutleeuw did not remain unaffected by the hand of God. The lack of a complete miracle collection precludes a detailed analysis, but it is safe to assume that the miracle of Paulus Gautier on 4 April 1612 was the first in a new series. This is suggested by the importance the churchwardens accorded this particular miracle and the renewed dynamics it generated, as clearly shown by their commissioning of the painting. While miracles from the sixteenth century are not recorded in the preserved churchwarden accounts, this event is amply documented. After the miracle occurred, a solemn Mass 'in gratitude' was performed in Saint Leonard's chapel, both on the day itself and on the day after. During these two days, the bells were rung, and the sextons and other ad hoc hired bell-ringers were paid in money and beer. ${ }^{93}$ Like elsewhere, this new miracle soon engendered others. The day after Gautier's healing, on Palm Sunday 1612, a second miracle was reported. Furthermore, in June the accounts mention another wonder, this time involving a woman, and on 20 September the bells were again rung as a miracle had happened with a man from the region around Leuven. Finally, in April 1616, a certain Livina de Hont claimed to have been miraculously cured from her lameness. The bells were rung and a 'Mass of devotion' was performed as usual, but this time the churchwardens also gave her a garment (lyffken) and some money to eat (teerghelt). ${ }^{94}$ Of course, many more miracles might have happened, but the evidence clearly suggests that Paulus Gautier was the first to have benefitted from Saint Leonard's renewed thaumaturgic powers. Hence, 1612 marked an important event in Zoutleeuw's cultic history.

\section{Restoration}

The first phase of the long civil war that followed the Wonderyear had disastrous consequences on life in the Low Countries, and this was particularly the case in Zoutleeuw. It is hard to assess the state of the cult of Saint Leonard during the years of war due to the absence of churchwarden accounts. Albeit still with some lacunae, the series only resumes with the account of 1589 (Appendix 1). Unusually, however, on its title page the clerk drew a group of ex-votos customarily offered to Saint Leonard - two legs, a chain and a crutch - thus visually harking back to the cult that had once constituted the main source of income for the Zoutleeuw fabrica ecclesiae (fig. 140). It is unclear whether these drawings were included as an expression 


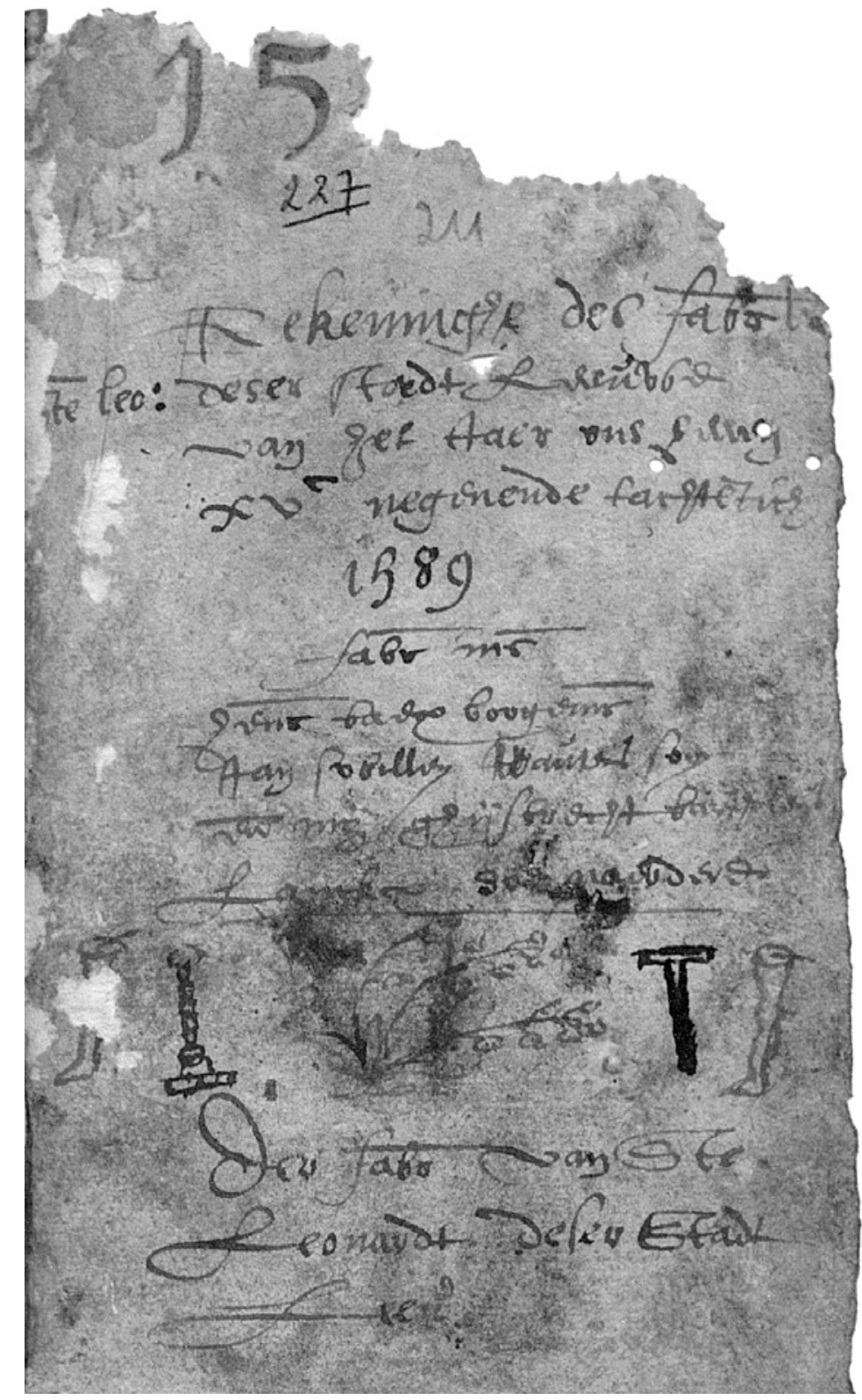

of hope for restoration or as a registration of new votives, but the nominal monetary offerings in any case suggest a steady increase throughout the 159 os and later years (graphs 2, 3 \& 4). And while the number of pennants is considerably lower than in the period before 1566 , the amount of purchased pilgrim badges gradually rose again, from 2016 in 1589 to 5040 in 1591 and 5112 in 1595 (graphs 5 \& 6). In
FIGURE 140

Title page of the 1589

churchwarden account,

Leuven, Rijksarchief, КАВ,

no. 1221, fol. 211 
short, the evidence suggests that the cult slowly re-established itself. This seems to be confirmed by active attempts at restoration. There is evidence for yet another type of devotional object being made available to the pilgrims around the turn of the century. While no copies of the pennants are known, there is still an engraved copper plate for a small devotional print in the church (fig. 141). It shows three pilgrims, in front of an enthroned Saint Leonard, bringing votive gifts such as a burning torch and a sack of corn. At both sides of the throne, ex-votos are hanging from rods, as was the case in the chapel of Zoutleeuw itself. At the bottom, a votive prayer sings the praise of the saint as patron of the town. ${ }^{95}$ Much like metal pilgrim badges and paper pennants, these small prints helped spread the word about the local cult, and encouraged devotion.

FIGURE 141

Anonymous, Engraved copper plate for a devotional print to Saint Leonard of

Zoutleeuw, late sixteenth or early seventeenth century,

Zoutleeuw, church of Saint Leonard

(C) KIK-IRPA, BRUSSELS

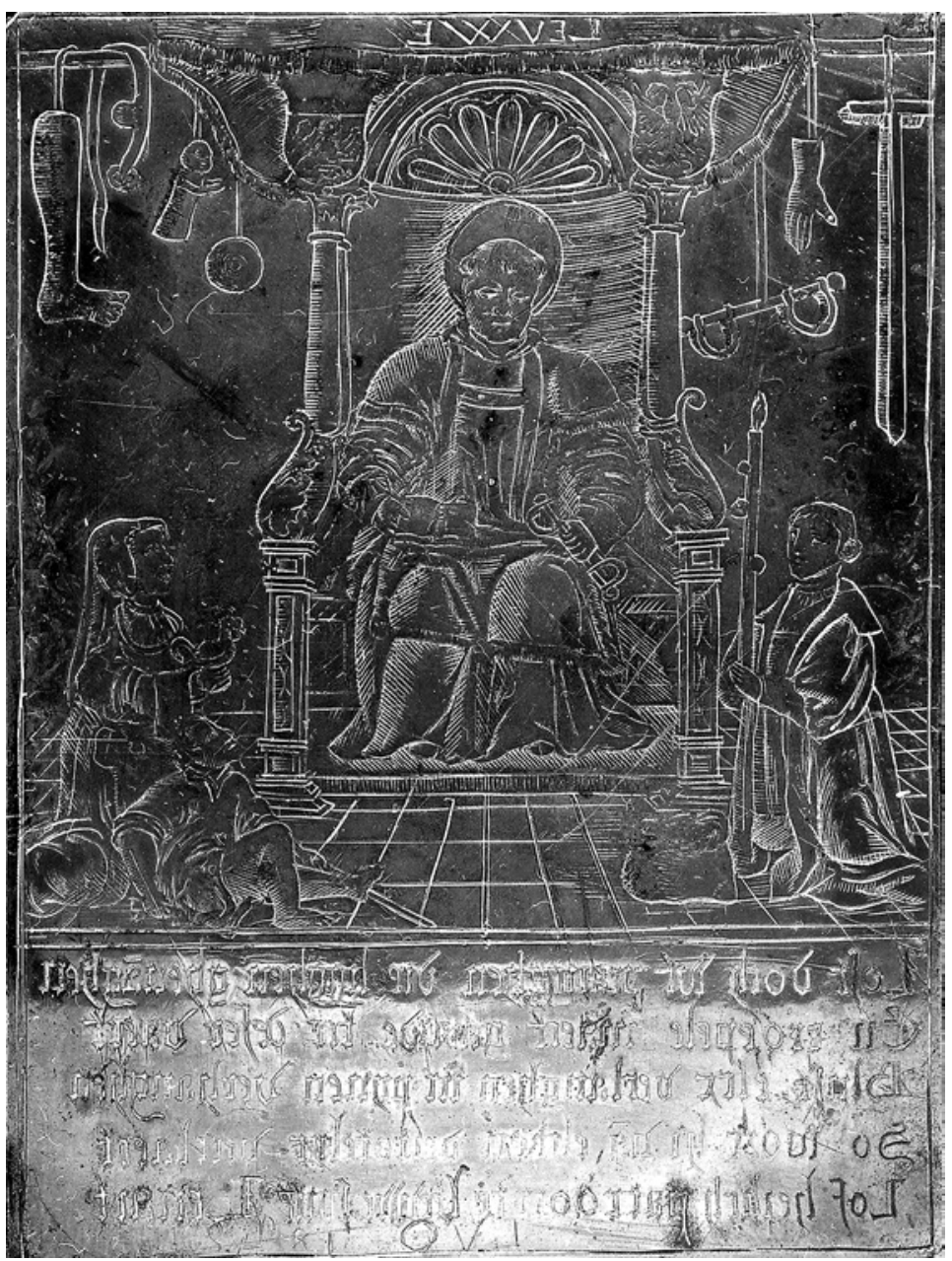


The most striking example of such restoring attempts, however, is the foundation, by dean Petrus Tielemans on 23 May 1597, of a festum recollectionis for Saint Leonard. Tielemans donated funds to the collegiate chapter in order to have Whit Monday - when the procession for the patron saint was traditionally held - celebrated in Zoutleeuw as a solemnity, a feast of first rank (festum prime classis). Money was allocated to cover the costs, including a distribution of payment among the canons as well as to the cantores, the sextons, the organ player, and for the lighting. ${ }^{96}$ The Latin verb recolere from the name of his foundation means 'to resume' or 'to rehabilitate', but it can also refer to the restoration of the honors due to statues in particular, which seems to be the case here, too. ${ }^{97}$ Furthermore, this rehabilitation also manifested itself materially. Over time, the cult statue of Saint Leonard has been repeatedly repainted - a recent investigation revealed at least five distinct interventions - and one of these layers of polychromy was clearly dated just above the front lower border of his vestments to 1587 (fig. 142). ${ }^{98}$

The miracles of 1612 and beyond thus occurred in the wake of a gradual re-establishment of the cult. The peaceful period of the Twelve Years' Truce (16o9-1621) provided the perfect context for the churchwardens to again put the cult on the map of Brabant's battered devotional landscape. The miraculous climate had affected the Hageland region too. New cult centers developed, Scherpenheuvel doubtlessly being the most important, and older cult centers of more modest geographical importance revived. In 1604 and 1605, miracles were recorded again at the shrine of Our Lady in Aarschot, two of which were also depicted on paintings. ${ }^{99}$ Similarly, the happy

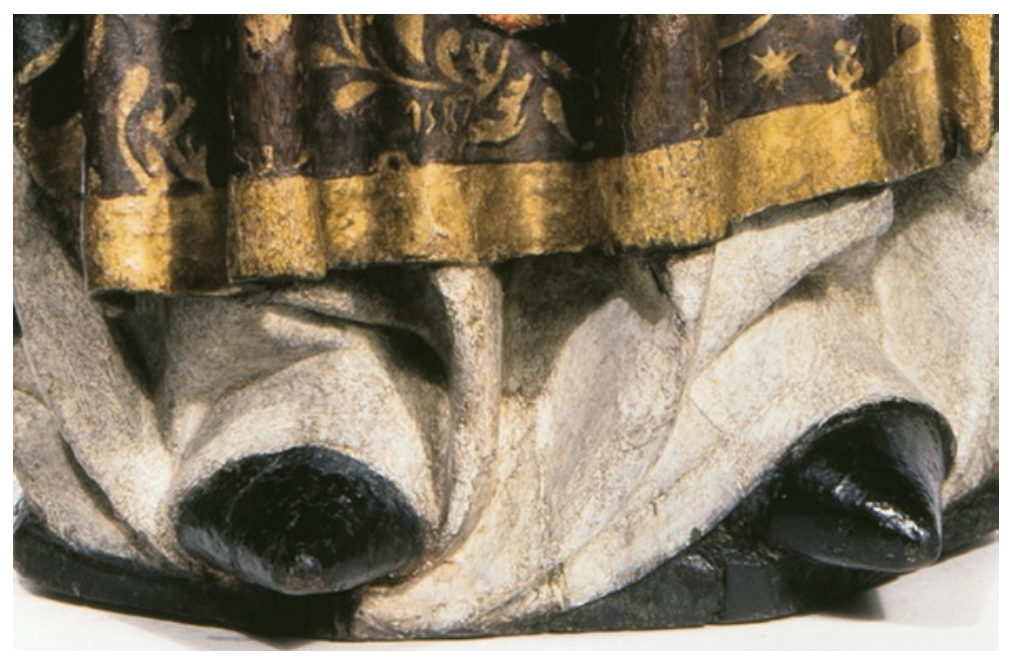

FIGURE 142

Detail of Fig. 18

(C) KIK-IRPA, BRUSSELS 
end of a grave accident during reconstruction works at the church of Wezemaal in 1607 was attributed to the miraculous powers of locally venerated Saint Job. ${ }^{100}$ And even though in 1596 the parish priest of Tielt (Brabant) had tried to collect evidence on the miracles worked by Our Lady before, the majority was still to come. On a total of 29 dated stories between 1572 and 1621, 25 occurred after 16o4, with a peak of 13 miracles in 1615 alone. Another five miracles were undated, but they must have occurred between 1594 and $1617 .{ }^{101}$ Since the war had had a devastating impact on the religious infrastructure, nearly all churches in the region were in need of material restoration. Zoutleeuw's church of Saint Leonard was spared of drastic damages, but the town had suffered greatly from military attacks and mutiny. ${ }^{102}$ Hence, the renewed prosperity that was promised by returning pilgrims was more than welcome. A new cultic competition between shrines was thus established, each promoting the benefits of their cult object, just as had happened a century before.

The churchwardens from Zoutleeuw were certainly aware of these developments. In 1598, for instance, they sent two employees to Our Lady of Halle. The precise nature of their mission is unknown, but upon their return they must have reported on some aspect of the newly intensified cultic activity at this important Marian shrine, in the wake of the increase of miracles that had occurred in the 159 os. ${ }^{103}$ What mattered most in the case of Zoutleeuw were of course the other places were Saint Leonard was venerated in the Duchy of Brabant and its neighboring territories (map 4, p. 95). In his discussion of Zoutleeuw from 1632, Wichmans particularly noted Sint-Lenaarts and Donk (near Aarle-Rixtel) as other places worth mentioning, but their relative importance at that specific moment is unclear. ${ }^{104}$ In Aartselaar, on the other hand, where Saint Leonard's cult had also peaked around 1500, the venerated relic was stolen by the Geuzen. But by the 162 os cultic activity must have been restored, since decanal visitation reports again refer to the pilgrimage as 'famous' (celebris, 1621) and mention that it attracted a lot of people (1628). ${ }^{105}$

For Zoutleeuw in 1612, the most relevant event was the cultic renewal at the Priory of Saint Leonard outside Liège. Seventeenthcentury authors maintained that miracles had occurred long before, but the earliest documented miracle in fact only occurred in 1605. ${ }^{106}$ On 25 February of that year, a ten-year-old boy who for six months had been unable to walk and was declared incurably ill by doctors, was suddenly healed in front of the priory's image of Saint Leonard. The case was immediately substantiated by parish priest Gilles Guillion (c. $1575^{-1620}$ ) 'to the confusion of heretics and 
iconoclasts' (ad confusionem haereticorum et iconoclastarum). The miracle was soon accepted as genuine by the ecclesiastical authorities, after which a procession was organized in gratitude, in which the boy himself walked barefoot as proof of the efficacy of the divine intervention through the image. ${ }^{107}$ The renewed religious activity it gave rise to was fostered by the publication - still in 1605 - of a book by Guillion containing this and other miracles. ${ }^{108}$ It was printed by Léonard Streel, who was actually born in Zoutleeuw but lived in Liège, and at least from 1592 onwards served as the standard supplier of printed material, especially pilgrimage pennants, to the church of Zoutleeuw. ${ }^{109}$ Hence, this news definitely must have reached Zoutleeuw. Interestingly enough, Liège theologian and chronicler Jean Chapeaville (1551-1617) mentions a certain Leonarda de Leeuwe as the mother of the boy. ${ }^{110}$ Although the toponym Leeuwe can refer to several places, at the time it was still the prevailing way to refer to Zoutleeuw, both in Latin and in Dutch (fig. 141). It is therefore tempting to assume that the family was believed to have come from Zoutleeuw, where they might have unsuccessfully tried their luck first. This is reminiscent of an ancient rhetorical trick in miracle stories, where previously tested yet unsuccessful shrines were named and listed explicitly, thus suggesting a rivalry with the other shrine for Saint Leonard in the region. The woman's first name as mentioned by Chapeaville - Leonarda - should further be considered a significant detail in this respect.

Coincidence or not, the first new miracle at Zoutleeuw also concerned the healing of a crippled boy - Paulus Gautier - exactly like what had happened in Liège a few years before. In order for the revival to be successful, the renewed miraculous activities of 1612 in Zoutleeuw had to be made known as widely as possible. The churchwardens deployed different techniques in order to do so. The first communication after the miracle had occurred was the ringing of the bells and the performance of a Mass. Soon after, they started using promotional devices that enlarged the geographical radius and, moreover, actively engaged the miraculé. Gautier was given food, clothes and several pairs of shoes for various trips in the wider region to spread the word about what had happened to him. A week after the miracle, he was sent to the nearby shrine of Hakendover to walk in the town's annual procession on Easter Monday to 'thank God that he was so miraculously cured'. He was also sent to Bastogne, 120 kilometers southeast of Zoutleeuw, and most interestingly also to Scherpenheuvel, together with a preacher. ${ }^{11}$ The reason for his trip to Bastogne remains unclear, but the other two destinations were clear publicity opportunities. All in all it was not uncommon 
for miraculés to be led in procession: we know of several medieval examples, and in 1605 , the same had already happened to the boy cured by Saint Leonard in Liège. ${ }^{112}$ However, these examples remained strictly local, in contrast with Gautier being sent to other communities and established cult shrines. Although the accounts stress that the ground for his participation in the Hakendover procession was the expression of his gratitude, another, probably at least equally important motivation, was to draw pilgrims to Zoutleeuw. The fact that a preacher was sent with the boy to Scherpenheuvel is telling in this respect.

The miracles from 1612 were also seized as an opportunity to request new indulgences from Pope Paul v (r. 1605-1621). In April 1613, the town council ordered the churchwardens to pay parish priest Willem Strauven (d. 1634) for travelling to the bishop in Mechelen to pick up 'the bulls of Rome from His Holiness'. The text of the indulgence was soon translated from the original Latin into the vernacular, and was subsequently spread in print form. In 1614, a bottresse - a female peddler from Liège - brought 150 'print letters to proclaim the indulgence', printed by Léonard Streel. This happened again in 1616.113 In April 1619, a new indulgence was obtained for a period of seven years, which again was translated. ${ }^{114}$ In all likelihood, the indulgence from 1613 had already been awarded in 1612 for a period of seven years, and was renewed in $1619 .{ }^{115}$ The text of one undated indulgence bull awarded by Pope Paul v for a similar period has fragmentarily been preserved in a Dutch version, on a large parchment sheet with rubrics (fig. 143). In a rather militant manner, the two most important holidays in Zoutleeuw were promoted: a plenary indulgence was awarded to those who, after having confessed and taken part in communion, visited Saint Leonard's church between the vespers of Pentecost and sunset on Whit Monday - i.e. the day of the yearly procession - and prayed there 'devoutly for the unity of the Christian princes, the eradication of heresy and the exaltation of our mother the Holy Church'. For those who did the same on Saint Leonard's day (6 November), an indulgence was granted for seven years and seven quadragenes, i.e. a period of 40 days. ${ }^{116}$

\section{The Intention of the Painting}

The painting commissioned to depict the miracle of 1612 thus fits in this strategy of spreading the word about the thaumaturgic powers of the cult statue in Zoutleeuw. It was not a genuine votive painting given by the miraculé as a token of gratitude, but commissioned and paid for by the churchwardens themselves. And although they must have been equally grateful for what had happened, it certainly 


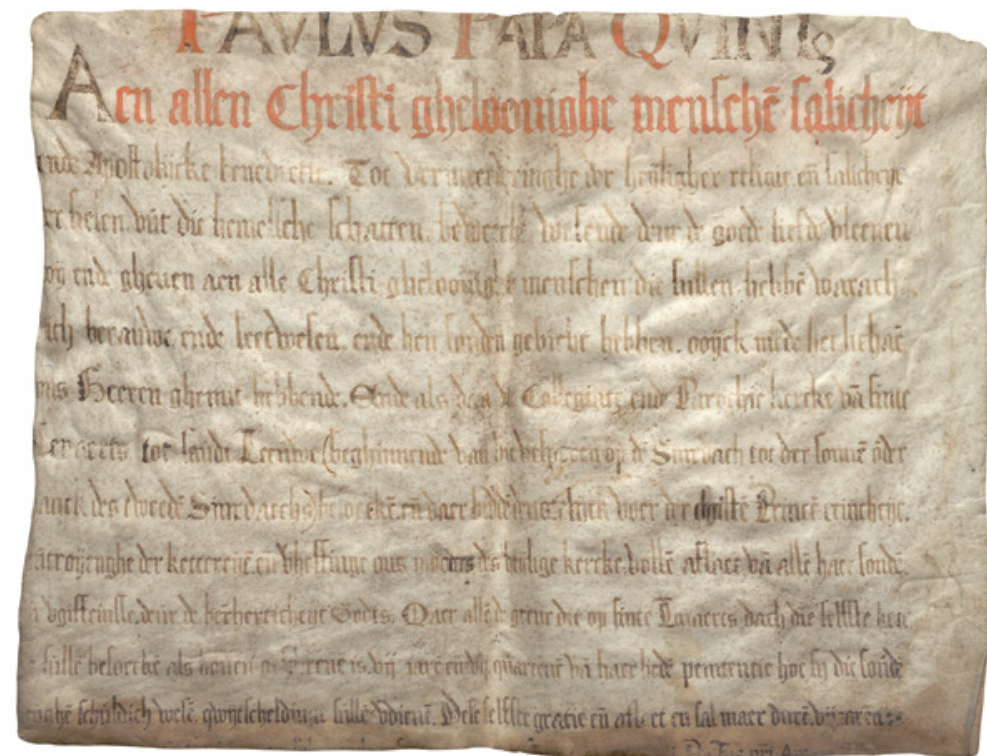

served as a promotional image. Evidently, Gautier was cherished at Zoutleeuw; he was provided with food and clothes and probably stayed in town for a while after the miraculous intervention. ${ }^{117}$ The outspoken communicative function of the painting is also clear from the fact that the explicative caption on the painting is rendered in both Dutch and French, exactly the two vernacular languages the indulgence bulls would be translated into. Similar efforts for bilingualism also appeared at other cult centers close to the linguistic border, doubtlessly with an eye toward expanding their potential audience. ${ }^{118}$ Much like Gautier being sent to other towns as a publicity device, the painting almost literally served as a permanent, visual signboard of a local miracle.

A whole range of media and material objects were used, as had been the case slightly over a century earlier. Still, some things had changed significantly. The pictorial genre was relatively new, and although it is unclear where exactly in the church the painting was originally located, it cannot have taken as central a place as the altarpiece that was commissioned in the 1470s. However, the most significant change is the new climate of miracles and the authorization of their validity. Before really making use of the advertising potential of these events for the local cult, the civic authorities made sure to have each case carefully investigated. At several occasions, delegates were sent to the places of origin of the people that claimed to have been miraculously cured in order to be certain about their previous state of health. For instance, after Gautier's claims, a burgomaster
FIGURE 143

Letter of indulgence awarded to the Zoutleeuw church of Saint Leonard by Pope Paul v, Leuven, Rijksarchief, кAB, no. 1240B 
travelled to Huy 'for an attestation of Paulus Gautier's paralysis'. The same happened following later miracles, when both the town clerk and the parish priest were sent to Geldenaken (Jodoigne). Interestingly enough, the various relevant entries in the accounts stress the necessity of having certainty (sekerheyt). ${ }^{119}$ This illustrates how the Tridentine procedure was actually applied in a specific context. Well before the ecclesiastical investigations, the magistracy rather than the clergy - of Zoutleeuw engaged in a substantiating dossier that was to be submitted for episcopal approval. ${ }^{120}$ The approval itself remains undocumented, as the miracles or the subsequent procedure are never mentioned in contemporary visitation reports, and no dossier has been preserved in the archiepiscopal archives. Still, the fact that indulgences were awarded confirms that there was papal approval.

This new context, with its heightened quest for certainty and objectivity, is equally embodied in the painting. In fact, Gautier not only served as a promotional tool, but also as piece of evidence. By sending him to shrines and processions, his body - the object of the miraculous change - served as the most direct proof of the veracity of the claims. It is a development which was typical for the period: the Tridentine emphasis on verification and approbation led to a shift in the precise nature of the reported miraculous interventions. They became predominantly physical or mental cures rather than nearmagical releases and liberations. Cures were indeed easier to verify, leading to an increasingly closer interaction between doctors and clerics in their quest to distinguish true belief from superstition. ${ }^{121}$ Thus, the painting depicting Gautier's body served as both a publicity device and a convincing argument against Protestant denials. This is clear from the contemporary terminology used to refer to the painting. In the entry in the accounts, it is called a contrefeytsel or likeness, a term which especially stresses the correct and objective representation of the subject. In early modern artistic discourse, it was used for images that had an ontological status of 'witness to material fact', most notably portraits. They were supposed to be an objective representation of the sitter, and therefore had to be transparent and show no signs of artistic invention. ${ }^{122}$ In a similar vein, Wichmans would later refer to the painting depicting the miracle at Our Lady of the Ossenweg from 1538 as 'proof' (argumenta) of the event. ${ }^{123}$

This tendency also had stylistic repercussions. As a result of the Protestant emphasis on the Word, the debate on images had led Catholic theologians to formulate a demand for realism and veritas historica. Images had to display the historic truth. Source material 
and texts needed to be examined critically, and painters were obliged to promptly use this information and represent things true to life in great detail. ${ }^{124}$ Jonckheere has shown how this resulted in a 'protoCaravaggesque naturalism' in Netherlandish painting of the later sixteenth century. ${ }^{125}$ In relation to Italian votive paintings, Fredrika Jacobs has stressed their testamentary value, arguing that they not only served as expressions of faith, but also as 'record of verifiable fact'. Interestingly, she pointed out that the typical, simple style of the paintings reflected unpretentious and genuine devotion. ${ }^{26}$ In the Low Countries, the genre became popular precisely in the decades preceding the commission of the painting from Zoutleeuw in 1612, which actually makes use of the very same conventions. Hence, it might have been a deliberate choice. The presence of an image resembling a votive painting in the immediate vicinity of the cult object suggested a broader popularity and effectiveness of said object, since 'genuine' votive paintings generally served as illustrations and tokens of efficacy.

Furthermore, the conspicuous absence of ingenious artistic skill was a conscious strategy to stress the veracity of the depicted scene. After all, exaggerated mannerisms and plain expression of creative inventio would immediately raise suspicion of invented or alternative facts. In the middle of the sixteenth century, Catholic theologians in Germany, most notably Hieronymus Emser, had contrasted 'simple' (schlicht) with 'artful' (künstlich), with simplicity serving as a synonym for honesty. Later, in 1570, Molanus also recommended a simplicitas maiorum. ${ }^{127}$ This was of course not, or at least to a much lesser extent, the case for miracles that had already been proven, most importantly those recorded in the Bible. For instance, when writing about Theodoor van Loon, who provided the newly built church of Scherpenheuvel with a series of altarpieces depicting the life of the Virgin, humanist Erycius Puteanus emphasized that he had rightly represented them as beautifully as possible, with the necessary rhetorical gaudery, since he was convinced that the divine manifested itself in beauty. ${ }^{128}$ This was not the case at all for miracles that were still in the process of being recognized and verified, either officially by the ecclesiastical authorities or unofficially by public opinion. Their images and depictions had to be as 'objective' and as 'clean' as possible in order to be convincing. Being a both clear and artistically unpretentious composition, Jacop Lambrechts' rendering of Gautier's miracle thus served this role as an 'objective' promotional image splendidly. The cult of Saint Leonard in Zoutleeuw revived modestly, and would soon catch the attention of the higher authorities. 